\title{
Az online oktatás tapasztalatai és gyakorlata a pedagógusok nézôpontjából
}

\begin{abstract}
A koronavírus-járvány miatt 2020 tavaszán bevezetett kényszerú távolléti oktatással kapcsolatban kérdóives felmérést végeztünk pedagógusok körében. A vizsgálat célja alapvetóen a kialakult helyzet felmérése volt. A kérdóivben egyrészt azt vizsgáltuk, hogy a pedagógusok milyen segitséget kaptak és igényeltek volna, másrészt a közérzetüket és az oktatás változásait vizsgáltuk, mind az alkalmazott módszerek, mind az általuk megitélt eredményesség tekintetében. Végül kérdeztük óket a diákokkal való kapcsolatukról és a diákok közérzetéról is. Eredményeink szerint a pedagógusok, bár jelentôs segítséget kaptak, de sokszor nem azoktól, akiktól szerettek volna. Alapvetóen informatikában jártas kollégák segítségét hiányolták, míg néhány esetben sokallották az intézmény vezetốjétôl, a munkaközösségtól, a barátoktól és egyes kollégáktól kapott segitséget.
\end{abstract}

\section{Bevezetés}

A z elmúlt tanév harmadik harmadában minden közoktatási intézménynek, majd a 2020/2021-es tanévben már változó mértékben, de minden iskolának szembe kellett néznie a távolléti oktatás kihívásaival. Ez a helyzet 2020 tavaszán váratlan és azonnali online oktatásra való átállási kötelezettséget jelentett a pedagógusok számára. Nem véletlen, hogy világszerte és nálunk is számos honlap foglalkozik azzal, hogy hogyan lehet megküzdeni ezzel a helyzettel.

Az oktatási rendszer müködésének színvonala a helyi sajátosságoktól függetlenül egy központi tényezőre vezethető vissza: a pedagógusok munkájának színvonalára. Több ország oktatási rendszerének összehasonlításával azt a következtetést lehet levonni, hogy az oktatás hatékonyságának legfóbb tényezői a pedagógusok (ld. az ún. McKinseyjelentést: McKinsey \& Company, 2007). A pedagógusok meghatározó szerepe nem csak általában igaz, hanem egy ilyen előre nem látott helyzetben még inkább igaz, hogy a hatékony müködés attól függ, hogy a pedagógusok mennyire képesek alkalmazkodni ehhez a helyzethez.

A pedagógusok munkavégzését befolyásoló tényező a pszichés állapotuk általában, és a kiégés mint veszélyeztető tényező. A kiégés okait a kutatások több irányból közelítik meg: a személyiségjellemzők (Holecz, 2006) mint hajlamosító tényezők, a tanári munka jellemzői, a szervezeti és szociális kapcsolati tényezők felől. Ebben a kutatásban 
a személyiségtényezőkkel nem foglalkozunk, azokra a szempontokra fókuszálunk, amelyekben a pandémia várhatóan változásokat, nehezedő körülményeket okozott. A szakirodalom a tanári pálya sajátosságaiból következő számos veszélyeztető tényezőt ír le (Benkovics-Parádi, 2017). Ebben a rendkívüli helyzetben több olyan körülmény is felerősödött, melyeket a kiégés lehetséges okaiként tartunk számon. A mi kutatásunk szempontjából ezek közül kiemelt jelentőségü a kiszámíthatatlanság a pedagógus pályán, amit a 2020-as pandémia mint kivédhetetlen külső tényező nagymértékben felfokozott. Nehezítő tényezőként érdemes megemlíteni továbbá a túlterheltséget, a magán- és munkahelyi tevékenységek összefonódását, az erősségek használatának ellehetetlenülését, a visszajelzések hiányát, hogy csak a legszembetünőbbeket említsük.

A kiégés-veszélyeztetettség szempontjából kiemelt jelentőségüek az oktatási intézmények szervezeti jellemzői és a pedagógusok közti kollegiális kapcsolat és együttmüködés. A kiégés a kutatások fényében összefügg a szervezeti jellemzőkkel, és a kiégés megelözésének fontos összetevője a személyközi kapcsolatok és a támogató szervezeti kultúra (Paksi és Schmidt, 2006). Ezért vizsgáljuk első kérdésként a pedagógusok által az iskolabezárás helyzetében igényelt és ténylegesen kapott támogatás mértékét és a támogatást nyújtók körét. A járvány következtében kialakult helyzetet jól írja le a kiégéssel kapcsolatos követelmények - kontroll - támogatás modell (Van der Doef és Maes, 1999). E modell szerint a kiégés oka az, hogy a szervezet vagy a betöltött munkakör követelményei magas elvárásokat támasztanak az egyén felé, ugyanakkor kevés lehetőség van a folyamatok kontrollálására. Ennek megterhelő voltát csökkentheti a munkahely által nyújtott támogatás, ami lehet formális elismerés vagy a körülmények biztosítása, de támogatást nyújthatnak a szervezet tagjai, a munkahelyi vezető vagy a kollégák is. Az itt bemutatott vizsgálatban mi nem a kiégés mértékét, csupán azokat a veszélyeztető tényezőket mértük fel, amelyeket a járványhelyzet valószínüsíthetően felfokozott. Ezek vizsgálatával a célunk az volt, hogy bemutassuk a pedagógusokra nehezedő pszichés teher összetevőit.

A pedagógusok hatékonyságát befolyásolja a pszichés állapotuk alakulásán túl a pedagógiai rátermettség és a módszertani felkészültség. A már említett McKinsey-jelentés a tanárok megfelelő kiválasztásán túl fontos szempontként a tanárok megfelelő képzettségét és a minden tanuló számára biztosított megfelelő oktatást, vagyis a differenciált bánásmódot azonosította. A jelenlegi helyzetben a két utóbbi szempont lehet releváns. A képzettség két összetevője játszhat itt kiemelkedő szerepet: egyrészt a digitális kompetenciák szintje, másrészt a módszertani jártasság, ami lehetővé tehetné a változó helyzethez való rugalmasabb alkalmazkodást, és általánosabb értelemben is a tanulókkal való egyéni bánásmódot. A vizsgálatunk arra irányult, hogy a jelenlegi online oktatási helyzetben változtattak-e, és ha igen, milyen módon változtattak a korábbi oktatási gyakorlatukon a pedagógusok, és figyelembe tudták-e venni a diákok eltérő igényeit. Vizsgáltuk továbbá, hogy milyen segítségre volt igényük maguknak az oktatóknak, és milyen támogatás volt számukra elérhető az online oktatással kapcsolatos technikai és tartalmi kérdésekhez.

Az iskolai oktatás hatékonyságának fontos tényezője az adott körülményeknek megfelelő oktatási módszerek megválasztása. Egy-egy módszer nem önmagában hatékony, vagy kevéssé az. Ezek célszerű megválasztását komplex szempontrendszer határozza meg. Szerepet játszik benne az oktatás célja, a tananyag jellemzői és a diákok sajátosságai is (Falus, 1999). Az online oktatás hatással van a módszertani eszköztárra: bizonyos módszereket nem, vagy csak jelentős átalakítással lehet alkalmazni.

Az oktatási módszerek közül a diákok aktivitását előtérbe helyező módszerek, főként a kooperatív oktatás használatának előnyét számos vizsgálat bizonyította a hagyományos oktatás keretei közt (Slavin, 1986; Kagan, 2001). Ennek alkalmazása javítja a diákok tanuláshoz és iskolához való viszonyát, elősegíti a csoporton belüli társas kapcsolatok alakulását, és segíti a tanulmányi eredmények, föként a gyengébben teljesítők 
eredményeinek javulását (Kagan, 2001; Aronson, 2008). Vizsgáltuk ezért, hogy a megváltozott helyzetben mennyire volt mód ezeknek a módszereknek az alkalmazására.

A diákok együttmüködésére épülő tanulás egyik figyelmet érdemlő és kevéssé kihasznált formája a tutorális tanítás. Itt a segítségre szoruló diákok idősebb, vagy akár az adott területen ügyesebb diákok segítségével sajátítják el az anyagot. Ebben a tutorok módszertani segítséget kapnak a pedagógusoktól vagy iskolapszichológustól (Bashian, 1989, idézi N. Kollár, 2017; Loke és Chow, 2005; Slavin, 2014). A megváltozott helyzetben az egyik erőforrás a jobb képességü tanulók idő- és tudásbeli kapacitásának használata lehetne - kérdés, hogy a tanulók együttmüködése e téren mozgósítható-e.

A McKinsey-jelentés által meghatározott harmadik fontos szempont, a diákok számára biztosított igényeik szerinti oktatás szintén összefügg a módszertani tudással, és a megválasztott oktatási módszerekkel is. Az online oktatás miatt változó körülmények és ezzel a pedagógusok bevált módszereinek szükségszerü felcserélése eddig kevésbé használt módszertani megoldásokra komoly kihívást és megterhelést jelent, ugyanakkor fontos összetevője lehet a diákok tanulmányi sikerességének.

Mindezen szempontok befolyásolják az online oktatás hatékonyságát, azonban mind a szervezeti szintü müködés, mind a szociális támasz nyújtása a pedagógusoknak, mind a digitális és szakmódszertani kultúra fejlesztése hosszú és összetett feladat. Ami azonban talán az eddigieknél könnyebben kézben tartható, az a pozitív tanár-diák viszony, a személyesebb kapcsolat kialakítása. A kutatások alátámasztják, hogy a tanár-diák kapcsolat szorossága, harmonikus, konfliktusmentes volta jelentősen járul hozzá a diákok tanulmányi sikereihez, különösen a hátrányos helyzetű vagy tanulási problémákkal küzdő tanulóknál. A pedagógussal való kapcsolat segíti a diákokat, hogy biztonságban érezzék magukat, kompetensebbnek tartsák magukat, harmonikusabb társas kapcsolataik legyenek a kortársaikkal (Hamre és Pianta, 2006; Slavin, 2014).

Hazai vizsgálatok is alátámasztják ezeket az eredményeket. A hátrányos helyzetü diákok nálunk is jobban igénylik a személyes törődést (Imre, 1999). Az iskolához való viszony és a tanulmányi eredményesség összefüggést mutat a pedagógusokkal való kapcsolat pozitív vagy negatív voltával, és az iskolához való viszonyt a pedagógusokkal való kapcsolat minőségén túl a kapcsolat személyessége is segíti (N. Kollár és mtsai, 1999).

\section{A kutatás módszere}

Online kérdöívvel vizsgáltuk a pedagógusok tapasztalatait a távolléti oktatással kapcsolatban. 2020 szeptemberében iskolapszichológusok a saját tantestületükben gyüjtöttek adatokat, majd decemberben és 2021 januárjában további pedagógusok véleményét kérdeztük hólabda-módszerrel. A kutatás az ELTE PPK Kutatásetikai Bizottságának 2015/251 és 202/544 engedélye alapján zajlott a pedagógusok névtelen és önkéntes részvételével.

Vizsgálatunk elsősorban feltáró jellegü volt. A pedagógusok által megélt tapasztalatokat vizsgáltuk, alapvetően abból a célból, hogy javaslatokat tudjunk megfogalmazni a nekik nyújtható segítség célszerü formáival kapcsolatban.

Egyrészt azt vizsgáltuk, hogy az online oktatás feladataiban a pedagógusok milyen mértékben kaptak és megfelelő forrásból kaptak-e segítséget. Másrészt a saját hatékonyságukról és közérzetükről, valamint a diákok pszichés jellemzőiről és tanulmányi teljesítmények alakulásáról kérdeztük őket. Módszertani szempontból az oktatásban alkalmazott módszerek változását vizsgáltuk: azt kutattuk, hogy a megváltozott körülményekhez jobban igazodó, vagy a kényszer szülte szükségmegoldások jellemzik-e az alkalmazott módszereket. A kutatás során a diákok kérdőíves vizsgálatát is elvégeztük, ennek eredményeit egy későbbi tanulmányban fogjuk bemutatni. 


\section{A minta jellemzői}

A minta 160 pedagógusból áll, a férfi válaszadók aránya $17 \%$, ami megfelel a pályán levők szokásos arányának.

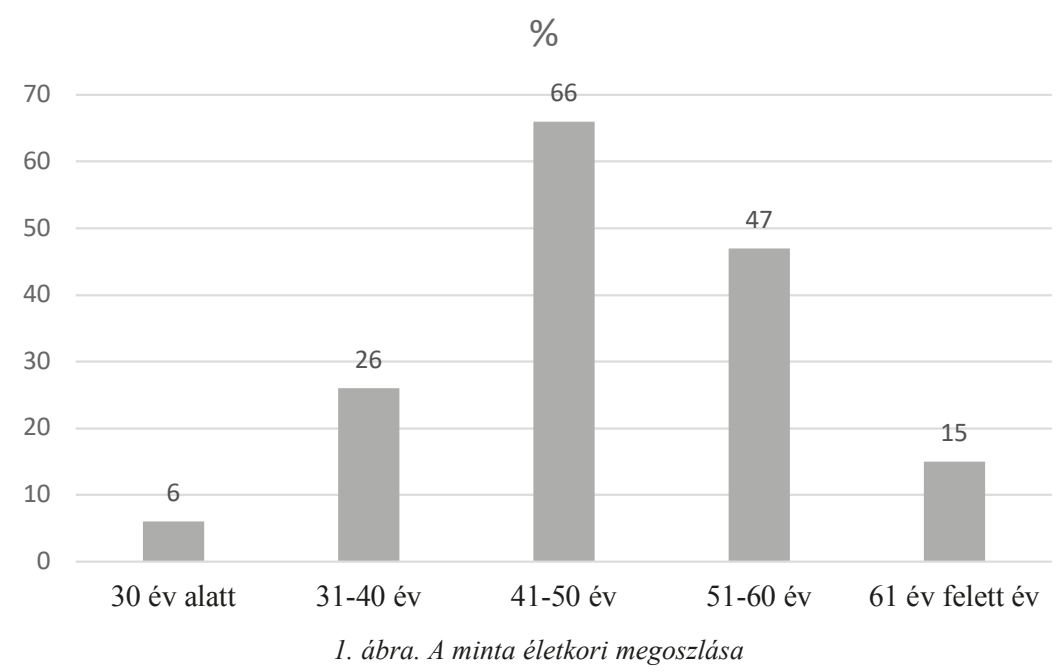

Az életkori összetétel szintén kiegyensúlyozott, kissé eltolódva az idősebbek felé. A legtöbben 41 és 51 év közöttiek, megoszlásukat az 1. ábra szemléleti.

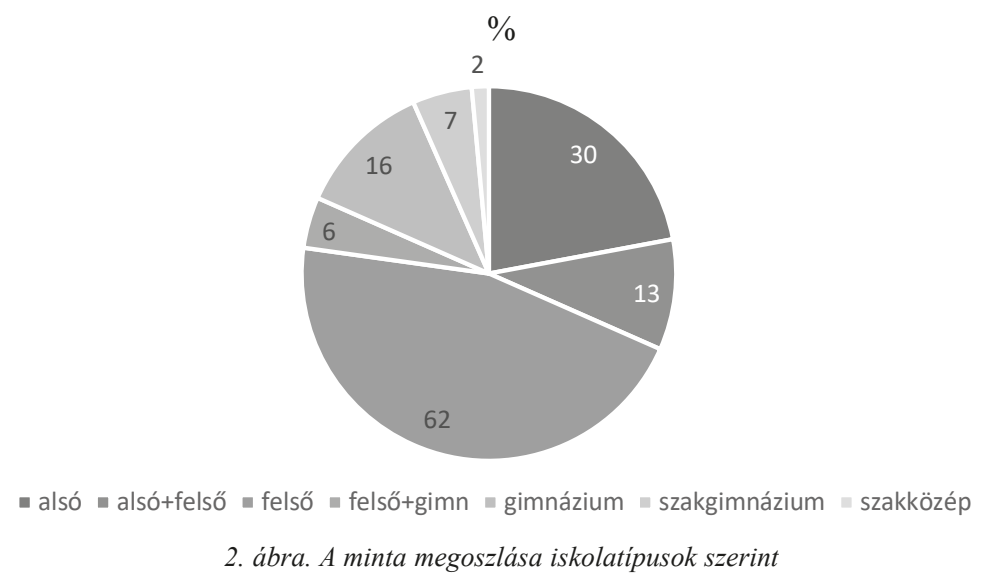

Iskolatípus vonatkozásában mind a szakgimnáziumok, mind a szakközépiskolák alulreprezentáltak. Az általános iskolai tanárok vannak túlsúlyban, közülük is a felső tagozatban tanítók. A gimnáziumi tanárokkal kapcsolatban fogunk tudni még jellemzőket megfogalmazni, de itt is csak megszorításokkal vonhatunk le következtetéseket, mert a mintában túlreprezentált a 6 és 8 osztályos gimnáziumi tanárok aránya (81\%). A szakközépiskolai tanároktól nem érkezett elég válasz ahhoz, hogy velük kapcsolatban is információkat szerezzünk (2. ábra). Így a minta alapvetően az oktatott diákok életkora szempontjából 
érdemel figyelmet, és a gimnáziumi mintára érdemes úgy tekinteni, hogy ezek azok a pedagógusok, akiknek a diákjai a legkevésbé problémás csoport tagjai.



3. ábra. Pedagógusok oktatott szakok szerinti megoszlása

A tanított tantárgyak tekintetében kedvező a kép, egyrészt azért, mert a minta arányaiban ebből a szempontból kiegyensúlyozott, kivéve a szakmai tárgyak oktatását, így lehetőségünk van a különböző szakcsoportokat tanítók jellemzőit is vizsgálni (3. ábra).

A tanítók, reál és készségtárgyak oktatóinak aránya közel egyenlő, a „vegyes” kategóriába olyan pedagógusokat soroltunk, akik humán és/vagy reál tárgy mellett készségtárgyat is tanítanak, a humán tárgyak oktatói nagyobb arányban töltötték ki a kérdőíveket. A kategóriák meghatározásánál, a szükségszerü összevonásoknál azt tartottuk szem előtt, hogy melyik tantárgycsoportok oktatása jelenthet hasonló problémákat az online oktatás során.

\section{A kapott segítség forrása és mértéke}

A pedagógusok 4-fokú skálán ítélték meg, hogy az adott személytől vagy csoporttól mennyi segítséget kaptak (semennyit, keveset, közepeset, nagymértéküt), és hogy ehhez képest mit tartanának ideálisnak, mit vártak volna el (ugyancsak négyfokú skálát használva). Mivel a pedagógusoknak nyújtott támogatás szintjét, és ehhez képest az igényeiket akartuk felmérni, nem a segítés számszerü mértéket, hanem az mértük fel, hogy ezt a segítséget ők mekkorának ítélik, és ezzel a segítséggel mennyire elégedettek. A következőkben először bemutatjuk, hogy a különböző személyektől vagy elérhető forrásokból átlagosan mekkora segítséget kaptak, összehasonlítva ezek egymáshoz viszonyított mértékét, majd megmutatjuk az egyes források által nyújtott segítség eloszlását is. A segítségnyújtás mértékének eloszlása azért érdemel figyelmet, mert a jelen szokatlan helyzetben fontos információ az is, hogy mekkorák az egyes pedagógusok közti különbségek. Végül megmutatjuk, hogy a kapott segítséghez képest mit igényeltek volna, vagyis, hogy mennyire vannak megelégedve ezzel a kapott segítséggel.

A források tekintetében számba vettük mind az iskolai, mind az intézményen kívüli lehetséges támogatásokat. Úgy véljük, hogy sikerült meghatározni a lehetséges segítők teljes körét, mivel mindegyik kategóriára érkezett érdemi válasz, ugyanakkor a szabad válasz: „egyéb forrás” kategóriára összesen két olyan válasz érkezett, ami a korábbi kategóriákba nem sorolható be, két személy kapott tanítvány szüleitől segítséget, és egyikük a férje volt tanítványától. Mindkét válasz csupán abból a szempontból érdemel figyelmet, mert jelzi, hogy a pedagógusok széles körben keresték a segítséget, ami a 4. ábrából is leolvasható. 


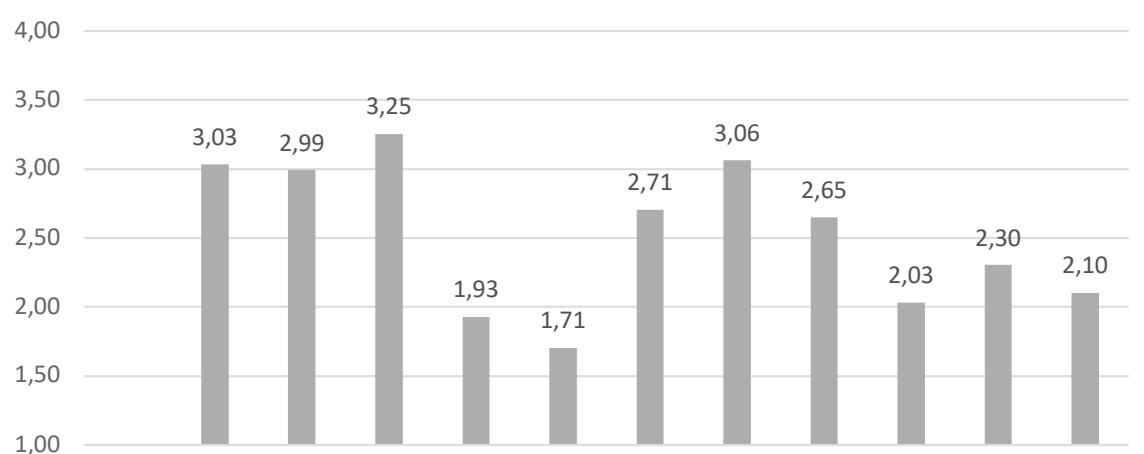

1,00

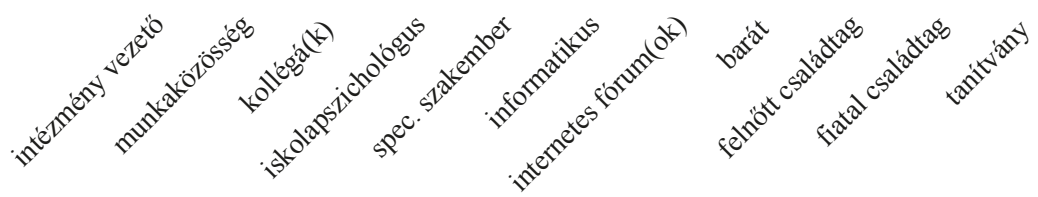

4. ábra. Iskolai és iskolán kívülröl kapott segitség átlagos szintje

A kapott segítség átlagát mutatjuk be a 4. ábrán. Az átlagok eltérését Friedmanpróbával, a páronkénti különbségeket kétmintás t-próbával mutattuk ki (Friedman-próba: $\mathrm{p}<0,001)$. Az ábrán a különbségeket eltérő színekkel jelöltük. A különböző forrásokból kapott segítség mértéke között jelentős a különbség. Legtöbb segítséget a kollégáktól kapták a pedagógusok (átlag: 3,25). Közepes mértékủ segítséget kaptak internetes forrásokból, honlapok, fórumok, linkek használatával, és ugyanilyen szinten tudtak támaszkodni az intézmény vezetőjére és a saját munkaközösségük támogatására. Az iskolában dolgozó, a foglalkozásuknál fogva az informatikában jártas kollégáktól (iskola informatikusa, informatikatanár) az elözőekhez képest kevesebb segítséget kaptak (átlag 2,71), ugyanolyan mértékben tudtak rájuk támaszkodni, mint az iskolán kívüli barátokra. Ennél is kevesebb segítséget kaptak a családjuk tagjaitól és az iskola segítő szakembereitől, ezen belül is legtöbb segítség a fiatal családtagoktól (saját gyermektől vagy unokától) érkezett, ami mutatja a fiatal generáció jártasságát ezen a területen. Már csak kevés segítségre számíthattak a saját tanítványoktól, felnőtt családtagoktól és az iskolapszichológusoktól. Végül a legkisebb segítség az egyéb segítő szakemberektől (fejlesztőpedagógus, gyógypedagógus stb.) érkezett. Az utóbbi két kategóriával kapcsolatban nincs információnk arról, hogy aki egyáltalán nem kapott ilyen segítséget, ott volt-e egyáltalán ilyen segítő szakember az
Legtöbb segítséget a kollégáktól kapták a pedagógusok (átlag: 3,25). Közepes mértékú segítséget kaptak internetes forrásokból, honlapok, fórumok, linkek használatával, és ugyanilyen szinten tudtak támaszkodni az intézmény vezetójére és a saját munkaközösségük támogatására. Az iskolában dolgozó, a foglalkozásuknál fogva az gáktól (iskola informatikusa, informatikatanár) az elözóekhez képest kevesebb segitséget kaptak (átlag 2, 71), ugyanolyan mértékben tudtak rájuk támaszkodni, mint az iskolán kivüli barátokra. informatikában jártas kollé- 
intézményben. Az iskolapszichológusi ellátásról tudható, hogy az iskoláknak csupán az egynegyedében van ilyen szakember alkalmazásban, de az egyéb szakemberek esetén is előfordul, hogy objektíve nem állnak a pedagógusok rendelkezésére.

A továbbiakban bemutatjuk, hogy az egyes források átlaga milyen válaszeloszlásból alakult ki.

\section{Segitség az intézmény vezetőjétöl}

A váratlan áttérés a távolléti oktatásra a vezetők számára is új helyzetet teremtett. Öket közvetlenül nem kérdeztük, de a pedagógusok által nyújtott adatokból is látszik, hogy nagy erőfeszítéseket tehettek a problémák megoldására (5. ábra).

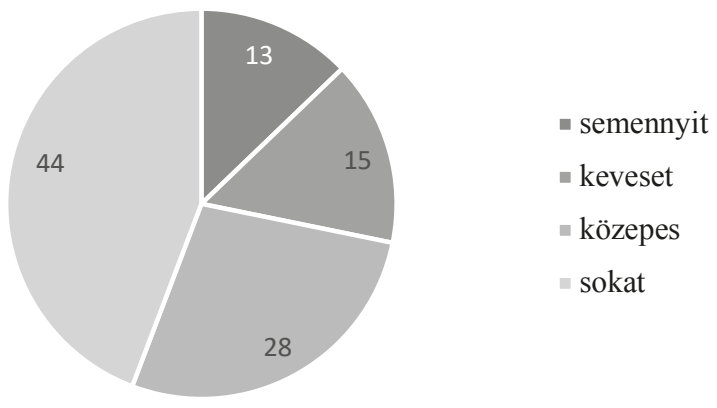

5. ábra. Az intézmény vezetőjétöl kapott segitség (\%)

Az intézmény vezetöjétöl meglehetösen sok személyes segitséget kaptak a pedagógusok, mint az elözöekben megmutattuk, csak az egyes kollégák segítettek ennél nagyobb mértékben. A minta 72\%-a kapott közepes vagy sok segitséget. Vagyis azt láthatjuk, hogy a vezetök felvállalták ennek a problémának a kezelését, és jelentös munkát fektettek a kollégák segitésébe.

\section{A munkaközösségtöl kapott segitség}

A leggyakoribb válaszok szerint a pedagógusok megkapják az esetek jelentős részében a kellő szakmai segítséget a munkaközösségektől (6. ábra). 38\% sok, 31\% közepes mértékü támogatást kapott.

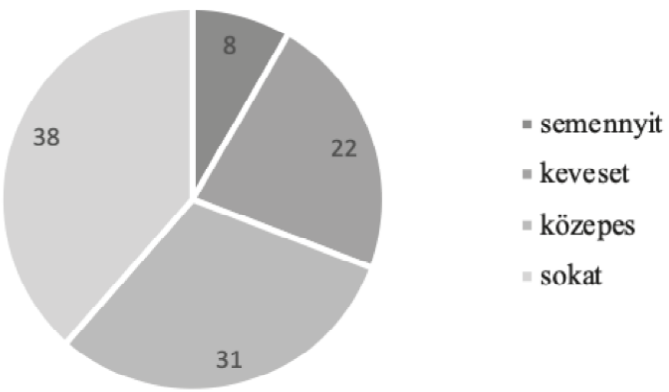

6. ábra. Szakmai munkaközösségtöl kapott segitség (\%) 
A kapott értékek az átlagot tekintve nagyon jók. Ugyanakkor elgondolkodtató, hogy a pedagógusok közel egyharmada kevés vagy semmilyen támogatást nem kapott a munkaközösségtől. A munkaközösség müködésének korábbi színvonala nagy valószínűséggel meghatározó a változott körülményekhez való alkalmazkodás szempontjából. Itt csupán egy tendenciát tudunk mérni, ami egy adott iskola különböző munkaközösségei esetén is eltérést mutathat. Érdemes azonban ezt a kérdést a konkrét intézmény szintjén vizsgálni, mert mint később megmutatjuk, a pedagógusok számára az informatikai eszközök használatán kívül a legnagyobb kihívást az a kérdés jelentette, hogy hogyan lehet az adott tárgyak oktatását átvinni az online térbe. Ehhez módszertani innováció kellene, aminek kidolgozásában a munkaközösségek játszhatnak nagy szerepet. Ez az esetek több mint harmadában ténylegesen sok segítség adását jelentette.

\section{Egyes kollégáktól kapott és várt segitség}

Mind az intézmény vezetője, mind a munkaközösség az iskolában betöltött szerepe következtében nyújt támogatást a pedagógusoknak. Az egyes kollégák már nem „hivatalból" segítséget nyújtó személyek, itt már az informális baráti kapcsolatok müködtetéséről is szó van (7. ábra).

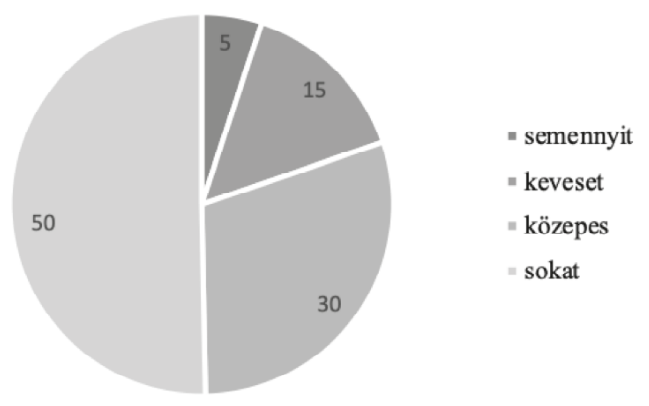

7. ábra. Egyes kollégáktól kapott segitség (\%)

Mint láttuk, a kollégáktól kaptak legnagyobb mértékű segítséget a pedagógusok, 50\% sok segítséget, további 30\% közepes mértékü segítséget kapott, és elenyészően kevés, $5 \%$ azok aránya, akik egyáltalán nem támaszkodtak kollégák segítségére. Ez az eredmény két szempontból érdemel figyelmet: egyrészt örömteli, hogy a tanári közösségen belül egymás segítése megvalósul, másrészt érdemes felfigyelni arra, hogy ez a segítség megelőzi a munkaközösségtől és általában az intézménytől kapott segítséget.

\section{Informatikustól, informatikában jártas tanártól kapott segítség}

Az iskola felől szervezeti szinten kapható segítség az intézményvezetőn és a munkaközösségen kívül a harmadik lehetséges forrása az informatikában végzettségénél fogva jártas kolléga, az iskola informatikusa és/vagy az informatikatanár. Nehéz kérdés ez, mert ők „hivatalból” nem kell, hogy segítsék a kollégákat, hiszen nekik is éppúgy vannak oktatáshoz kapcsolódó vagy közvetlen oktatási feladataik. Másrészt az is probléma, hogy számarányuk a segítendő kollégákhoz képest csekély. Azonban azt láthatjuk a 8. ábrán, hogy ez a segítség lényegesen kevesebb, mint amit a szakértelemmel képzettségüknél fogva kevésbé rendelkezőktől kapnak a pedagógusok. 


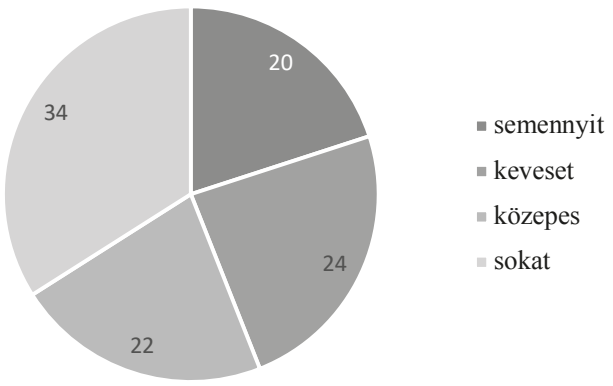

8. ábra. Az informatikában jártas kollégáktól kapott segitség (\%)

Vizsgálatunk alapkérdése, hogy mit célszerü tenni a válaszok tanulságai alapján. Az iskolai informatikusok kapacitását érdemes lenne szervezett formában használni, amiben mozgástere az intézmények vezetőinek lehet. Arra gondolunk, hogy az informatikában jártas kollégák energiáit a pedagógusok képzésére és a pedagógusok körében a potenciális mentorok felkészítésére és a tantestületen belüli mentori rendszer kialakítására is lehetne fordítani. Ebben az informatikatanárok szerepe kitüntetett lehetne: talán szokatlan a felvetés, de úgy gondoljuk, hogy ebben a rendkívüli helyzetben indokolt lehetne a hagyományos informatika tananyag tanítása helyett mind a pedagógusok, mind a diákok célzott képzése az online oktatáshoz szükséges tudás területén. A jelenlegi helyzet rendkívül látványosan mutatja az IKT-tudás fontosságát, ez hosszú távon általában is nyereség lehet az informatikaoktatás szempontjából, és motivációnövekedést is eredményezhetne, amennyiben a különböző IKT-technológiák egyre önállóbb használata sikerélményt jelentene a diákoknak.

Az informatika területén nem csak az iskolán belül kapható segítség, hanem az interneten is, ezt a válaszok alapján a pedagógusok ki is használták (9. ábra).



9. ábra. Internetes fórumoktól kapott segitség (\%)

Az informatikában jártas kollégáknál nagyobb arányban, 72\%-ban az internetre támaszkodnak a pedagógusok. Az internetes források kétségtelen előnye, hogy a hozzáférés szinte mindenki számára biztosított. Akik kevéssé vagy egyáltalán nem használják $(22 \%)$, azoknak valószínüleg technikai segítség hiányzik, ami talán a legkönnyebben orvosolható lenne. A pedagógusok részéről felmerül a szöveges válaszokban korlátként a kellö mennyiségü digitális tananyag hiánya is. 


\section{Iskolapszichológustól és más segitő szakemberektől kapott segitség}

A két csoporttól kapott és várt segítség mértéke hasonló. A kettő korrelációja magas (kapott $\mathrm{r}=0,53$ ), párosított t-próbával a kettő közti különbség $\mathrm{p}<0,05$ szignifikáns, az iskolapszichológustól valamennyivel több segítséget kaptak, de mindkettő szintje viszonylag alacsony (átlagok: 1,93 és 1,71). Ezért a két csoporttal kapcsolatos tapasztalatokat és elvárásokat együtt jelenítjük meg (10. ábra).



10. ábra. Az iskolapszichológustól és más segitö foglalkozásúaktól kapott segitség (\%)

A kérdezettek több mint fele semennyi segítséget nem kap ezektől a szakemberektől, további $14-15 \%$ keveset. Miért és milyen segítséget kaphatnának ezektől a szakemberektöl a pedagógusok? Hogy kaphatnak, azt mutatja, hogy ha nem is sokan, de néhányan kapnak: az iskolapszichológustól 15\% sokat, 17\% közepes mértéküt, az egyéb szakemberektöl pedig 9\% sokat, illetve 14\% közepes mértéküt. Az iskolapszichológus két területen is tudja támogatni a pedagógusokat: egyrészt maguknak a pedagógusoknak mentális segítség nyújtásával ebben a kritikus időszakban, másrészt a diákokkal való bánásmód, főként a diákok pszichés támogatásának mikéntje tekintetében és az online oktatás idején felmerülő egyéni problémák kezelésében. Ez a kérdőív és a már említett diák kérdöívünk is abból a célból született, hogy ennek eredményeit az iskolapszichológusok a pedagógusokkal és az iskolavezetéssel folytatott konzultációkban felhasználhassák.

Az egyéb szakemberek a különleges bánásmódot igénylő diákok oktatásának módszereiben tudnak szempontokat nyújtani. Ez az egyik olyan diákcsoport, akiket az online oktatás különösen próbára tehet, és az a veszély fenyegeti öket, hogy tovább nőhet a lemaradásuk a tanulásban. 


\section{Informális segítség: iskolán kívüliek és saját diákok}

A pedagógusok kaptak segítségek az iskolától független személyektől, barátoktól, családtagoktól és a saját diákjaiktól is (11. ábra). Jelentős ez a segítség még akkor is, ha, mint láttuk, a barátok kivételével a korábbiakhoz viszonyítva tőlük kapnak a legkevesebbet. Az átlag a 2-es érték, vagyis a „kevés” kategória körül van.

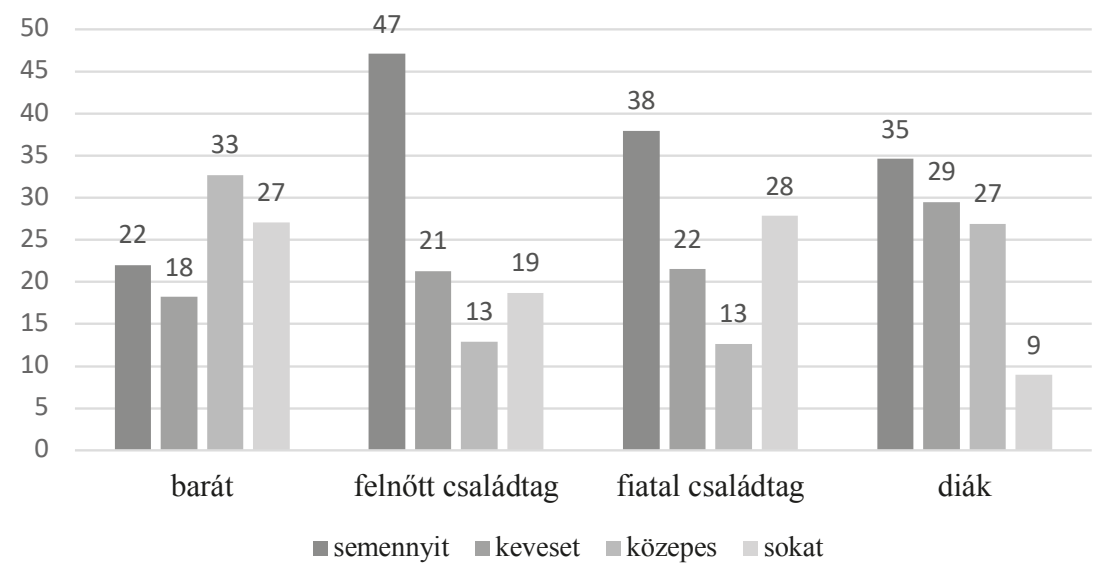

11. ábra. Iskolán kívüli barátoktól, felnött családtagoktól, saját gyerektöl vagy unokától és a saját tanitványoktól segitséget kapott pedagógusok aránya

Legtöbb segítséget a barátok nyújtottak, a tőlük kapott támogatás egy szinten van az iskola informatikában jártas munkatársai által nyújtottakkal. A pedagógusok $27 \%$-a sok segítséget kap tőlük, és további 33\% közepes mértéküt, vagyis $60 \%$ számára elérhető olyan barát, akire támaszkodhatnak.

Örömteli módon számottevő segítséget kaptak a fiatal generáció tagjaitól, jobban a családtagoktól, mint a diákoktól, valamint a diákokkal azonos mértékben, közepes vagy sok segítséget 32\%-ban a felnőtt generációtól.

\section{A ténylegesen kapott segítség a pedagógusok elvárásaihoz képest}

A kapott segítség megítélésében két szempontot vizsgáltunk. Minden pedagógus esetén összehasonlítottuk az általuk ideális esetben elvárt támogatás szintjét a ténylegesen kapott segítség mértékével (személyenként kivontuk a várt értékből a kapott értéket), majd kiszámoltuk az így kapott értékek mintaátlagát. Másrészről megvizsgáltuk a válaszok eloszlását, a vártnál kevesebbet kapottakat (kevésnek találja a támogatást) az elégedettekkel (annyit kapott, amennyit szeretett volna) és a segítséget soknak találókkal (többet kapott, mit amennyit optimálisnak tart).

Először a mintaátlagokkal kapcsolatos tanulságokat vesszük számba (12. ábra).

A kapott átlagokat a 0 várható értékhez (annyit kaptak, amennyit szeretnének) viszonyítva egymintás t-próbával ellenőriztük, hogy a pedagógusok megfelelőnek, kevésnek (pozitív irányú eltérés) vagy túlzottnak tartják-e a kapott segítséget (negatív érték). 


\begin{tabular}{|c|c|c|c|}
\hline \multicolumn{4}{|c|}{ 1. táblázat. Várt és kapott segitség közti különbség átlaga és az összetartozó mintás t-próba eredménye } \\
\hline & Várt-kapott átlag & $\mathbf{t}$ & Szig. (2-oldalú) \\
\hline Vezető** & ,26 & 3,214 &, 002 \\
\hline Munkaközösség*** &, 37 & 4,557 &, 000 \\
\hline Kollégák & 04 &, 512 & n.s. \\
\hline Iskolapszichológus*** & ,49 & 5,653 &, 000 \\
\hline Egyéb segítő szakma képviselője*** & ,57 & 7,100 &, 000 \\
\hline Informatikus $* * *$ & ,62 & 6,529 &, 000 \\
\hline Internetes fórum &,- 02 &,- 355 & n.s. \\
\hline Barát &,- 01 &,- 212 & n.s. \\
\hline Felnőtt családtag &,- 01 &,- 134 & n.s. \\
\hline Fiatal családtag &, 00 &, 000 & n.s. \\
\hline Tanítvány+ & 13 & 1,961 & 052 \\
\hline
\end{tabular}

Az 1. táblázatból azt láthatjuk, hogy a kollégáktól, internetes fórumoktól, az iskolán kívüli személyektől, baráttól, családtagoktól, valamint a tanítványoktól megkapták azt a mértékü segítséget - legalábbis a minta egészére nézve -, amekkorát elvártak. Legkevésbé az informatikában jártas kollégától kapott segítséggel elégedettek - az előzőekben láthattuk, hogy a kapott segítség mértéke is kevesebb, mint a vezetőtől vagy munkaközösségtől kapott segítség. Ez utóbbiakkal szemben is nagyobb lenne az elvárásuk, de ennek átlagértéke már csak 0,37 (munkaközösség) és 0,26 (vezetö). Viszonylag nagy még a nem teljesült elvárás az iskolapszichológus és egyéb segítő szakemberek felé, de itt, mint láttuk, másról van szó, mint az informatikus esetén, mert ezeknél a szakembereknél a nyújtott segítség alacsony szintü, ehhez képest várnának kicsit többet.

\section{A pedagógusok elvárásaihoz képest ténylegesen kapott segítség az iskolán belül}

Az elégedettség átlagos értékén túl az elégedettség, illetve elégedetlenség mértéke is informatív. Az ábrán a vágyott szintnél több segítséget igénybe vett, annyit kapott, mint amennyit szeretett volna, és a többet igényelne, mint amennyit kapott személyek százalékát tüntettük fel.

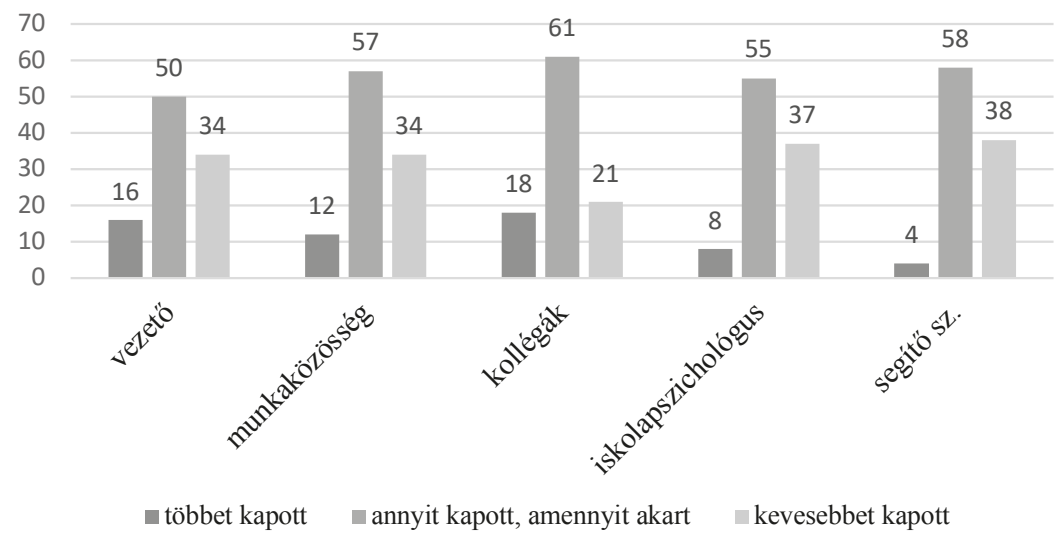

12. ábra. Iskolavezetés és kollégák által nyújtott segitséggel elégedettek és elégedetlenek aránya 
Az eddigiekben azt láthattuk, hogy az iskola vezetésétől meglehetősen sokan kaptak sok vagy közepes mértékü segítséget. Az elégedettség átlagos szintjéböl (1. táblázat) azt is láthattuk, hogy még több segítségre tartanának igényt. A 12. ábrán látható eloszlásból azonban az is látszik, hogy meglepő módon $16 \%$-a a pedagógusoknak sokallja ezt a segítséget. A miértekre ebből a vizsgálatból nem tudunk választ adni, azt azonban megfogalmazhatjuk, hogy nekik nem esett jól, vagy nem tartják ideálisnak, hogy a vezető segítségére szorulnak. A mintavételi szempontok szerinti almintákat vizsgálva azt találtuk, hogy a segítség igénylése vagy elutasítása független a nemtől, iskolatípustól, az oktatott szaktól és az életkortól is (egyszempontos varianciaanalízis szerint nincs különbség a mintaátlagok közt, a továbbiakban: n.s.).

Nem tudjuk pontosan, mi lehet a segítség sokallásának a hátterében. Nehéz elfogadni a vezetőtől a segítséget, vagy úgy gondolják, másoknak kellene inkább segíteni? A későbbiekben ez utóbbi szemponthoz lesznek még adataink. Az sem kizárható, hogy magának a segítésnek a tartalma, formája nem volt ideális számukra. További vizsgálatok és talán leginkább a helyi munkahelyi klíma ismerete adhatna erre választ.

A munkaközösségtől a pedagógusok több mint fele olyan mértékü segítséget kapott, mint amilyet igényel, ami, tekintettel a helyzet újszerüségére, kifejezetten jó aránynak tekinthető. Érdekes viszont, és a vezetővel kapcsolatos elégedetlenség irányával azonos jelenség, hogy ha arányában kisebb mértékben is, de $12 \%$ itt is sokallja a kapott segítséget. A segítség igénylése vagy elutasítása eben a kérdésben is független a minta objektív jellemzőitől.

A pedagógusok 61\%-a a kollégáktól megkapja azt a mértékü - jellemzően közepes vagy sok - segítséget, amit szükségesnek érez. Kiegyensúlyozott azok aránya, akik többet szeretnének, de nem volt rá mód (21\%), és azoké, akik szeretnék, ha ez kevesebb lehetne (18\%). Jellemzően azok dominálnak ebben a csoportban, akik sokat kaptak, és szeretnének egy kicsit kevesebbet $(15 \%$ a sokat kapott és közepes mértéküre vágyók aránya) - ha egyszerüen fogalmazunk, ők túlzottnak érzik, amilyen mértékü szívességet kértek és kaptak.

A pedagógusok a segítő szakemberekről, iskolapszichológusról és fejlesztőpedagógusról stb., mint láttuk, kevés segítséget kaptak. A többség azt gondolja, hogy ebben a helyzetben kevés segítséget is nyújthatnak ezek a szakemberek. Így viszonylag magas a kapott segítség mértékével való „elégedettség”. Azt gondoljuk, hogy ennek az eredménynek három tanulsága is van. Egyrészt fontos lenne, hogy ezek a szakmák jobban megmutassák, hogyan válhat a közreműködésükkel hatékonyabbá az oktató-nevelö munka. Másrészt az eredmény összefügghet a segítő szakemberek alacsony számával az intézményekben. S végül az sem elhanyagolható szempont, hogy a koronavírus-járvány ezeket a szakembereket is merőben új feladatok elé állította, és ahhoz, hogy ebben a módszertani szempontból újszerü helyzetben hathatós segítséget nyújthassanak a pedagógusoknak, az kellene, hogy ezen a területen nagyobb hagyománya legyen a közös munkának, különösen az eltérő nevelési igényü tanulók segítésében. Az igény a pedagógusok részéröl létezik, ha csekély mértékü is: 37 , illetve $38 \%$ szeretne több segítséget kapni, jellemzően egy keveset, vagy közepes mértéküt. 


\section{A pedagógusok elvárásaihoz képest ténylegesen kapott segitség} az informatika és online világ területén

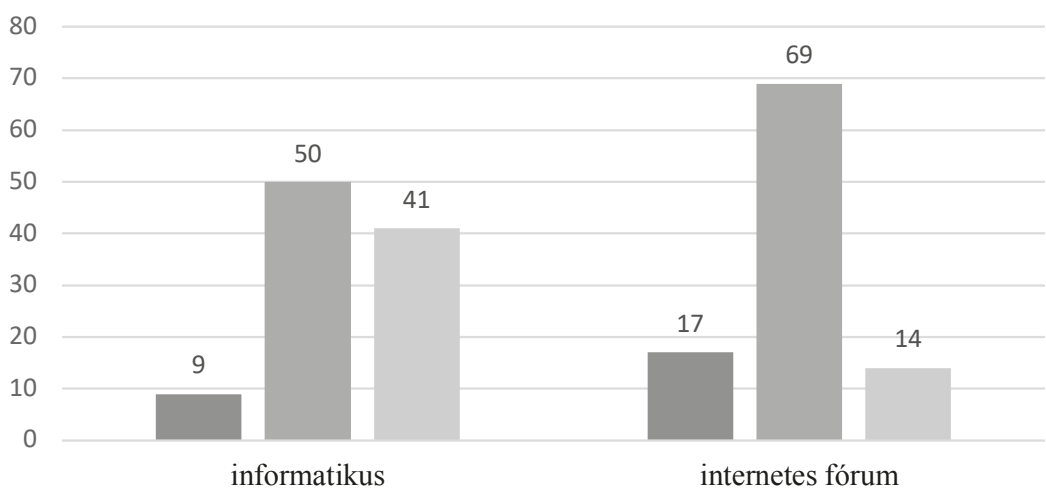

13. ábra. Az informatika területén kapott segitséggel való elégedettség

Az eddigiekhez képest mintha megfordulna a kép, és legalább részben választ is kapunk arra a kérdésre, hogy ha nem a vezetőtől és a munkaközösségtől, akkor kitől várnák a pedagógusok segítséget.

A várt és kapott segítség mértéke a válaszadók 50\%-ánál egybeesik, közel ilyen arányban (41\%) több segítség kellett volna. Vagyis egyértelmüen azoktól várnák a segítséget, akik vélhetően azzal a speciális tudással rendelkeznek, ami a pedagógusoknak hiányzik.

Az internetes fórumokat, honlapokat nagymértékben használják, és ennek mértékével nagy arányban elégedettek is a pedagógusok. Bár itt is vannak, akik ennek használatával kapcsolatban fenntartásokat fogalmaznak meg. 11\% egyáltalán nem, vagy csak kevéssé használ ilyen anyagokat vagy tanácsot, és azt is gondolja, hogy ez így van jól, 15\% viszont közepesen vagy sokat használja ezeket a forrásokat, de kifejezetten kevesebbet szeretne erre támaszkodni. A korábbiak alapján valószínü, hogy ez utóbbinak a magyarázatát a többi forrás elégtelenségében lehet keresnünk.

\section{A pedagógusok elvárásaihoz képest ténylegesen kapott segitség az iskolán kívül és a saját tanítványoktól}

Az iskolán kívüli források közül a baráttól kaptak a pedagógusok a legtöbb segítséget, és ezzel a leginkább elégedetlenek mindkét irányban, 17\% még többet szeretne kapni, 18\% viszont kevesebbet (14. ábra). 




14. ábra. Az iskolán kivüli segitöktöl és a saját tanitványoktól kapott segitséggel való elégedettség

A nem hivatalos források, vagyis azon személyek közül, akik „hivatalból” nem kell, hogy segítsenek, a saját tanítványok azok, akiktől jelentősen több segítséget szeretnének kapni a pedagógusok. Ez egyrészt mutatja a pedagógusok nyitottságát arra, hogy elfogadják a segítséget, azonban ehhez a képhez az is hozzátartozik, hogy a tanítványoktól kapott segítségnek csupán 10\%-a jelentős mértékü, és ennek 7\%-át sokallják is a pedagógusok. Akik több segítséget szeretnének, 20\%-ban keveset vagy közepes mértéküt szeretnének, és csupán 4\% szeretne sok segítséget a kevés vagy közepes helyett. Vagyis a pedagógusok jellemzően mérsékelt segítségre vágynak a tanítványoktól.

A vélemény a barátoktól kapott segítséggel dominánsan (65\%-ban) az elégedettség. Érdekes adat továbbá, hogy $15 \%$ egyáltalán nem vett igénybe ilyen segítséget és nem is igényli. $17 \%$ több segítséget igényelne, de jelentős, $18 \%$ azoknak az aránya is, akik a kapott segítséget sokallják. Nyilván nem azt nehezményezik, hogy kaptak segítséget, hanem itt ugyanazt a jelenséget észlelhetjük, mint az első két vizsgált csoportnál: jobban örülnének, ha nem kellene ezt a segítséget igénybe venni. Nem tudjuk, hogy ezt azért gondolják, mert mástól várnák a segítséget (mint láttuk, leginkább az informatikusában jártas kollégáktól), vagy azt szeretnék, hogy segítség nélkül is boldoguljanak. A feladat azonban mindkét esetben ugyanaz lehet: a pedagógusok IKT-kompetenciáit érdemes fejleszteni.

A családon belüli segítségről azt lehet még elmondani, legyen ez felnőttől vagy fiataltól kapott segítség, hogy megkapták az igényelt segítséget (felnőttől 79\%-ban, fiataloktól 75\%-ban), a fiataloktól, mint láttuk, mennyiségét tekintve többet. A tanítvánnyal kapcsolatban már kicsit színesebb a kép, az igényelt és kapott segítségben is dominál a kevés vagy közepes mértékü segítség.

Tanítványok esetén a kapott segítséget 24\% tartotta kevésnek, az elégedettek aránya itt $61 \%$, és azt láthatjuk, hogy a tanítványoktól szívesen veszik a segítséget, az ezt sokallók aránya $15 \%$, alig több mint a fiatal családtagok esetén (13\%)

Összességében az állapíthatjuk meg, hogy leginkább az informatikában jártas kollégáktól szeretnének több segítséget kapni a pedagógusok. Elsősorban a barátokkal, munkahelyi kollégákkal és vezetővel kapcsolatban és az internetes források esetén fogalmazzák meg legtöbben (16-18\%), hogy nem ezektől a személyektől vagy eszközöktől szeretnék a segítséget megkapni.

Végül a segítséggel kapcsolatban egy nyitott kérdést is feltettünk: Mi az, ami még segíthetne a pedagógusok munkájához, ha újra online kellene tanítani? A pedagógusok elsősorban a technikai feltételek biztosítását, a használható online tananyagokat és a saját 
IKT-kompetenciájuk fejlesztését említették. Megjelent a válaszokban ezzel kapcsolatban olyan probléma is, hogy a 400 fös iskolából 100 tanulót technikai eszközök hiányában interneten egyáltalán nem lehetett elérni, ami a hátrányos helyzetủek fokozottabb problémáihoz vezető szempont.

A válaszokban megjelent az iskola és a munkaközösség részéröl nyújtott segítség abban a kérdésben, hogy mit hogyan, milyen technikai megoldásokkal célszerü elvégezni a tanítás során. További szempont volt az érintettek közti jobb kommunikáció, a pedagógusok rendszeres megbeszélései, a szülőkkel való jobb kommunikáció és a diákokkal folytatott informális beszélgetés is. Egy-egy pedagógus konkrét igényt fogalmazott meg azzal kapcsolatban, hogy szeretne megbízható módszert kapni a diákok tudásának felmérésére, illetve szeretné, hogy „a szülők informatikai tudása fejlődne”. Ez utóbbiból látszik, hogy esetenként a szülők segítségét is igyekeztek igénybe venni.

\section{Szubjektív élmények az online oktatás során}

Az online oktatás alapvetően változtatta meg az oktatás körülményeit. Az eddigi bevált kommunikációs, tanítási és értékelési módszerek helyett más megoldásokat kellett választani. A kérdőív következő szakaszában három szempontból ítéltettük meg a pedagógusokkal a közérzetüket 5-fokú Likert-skálán. A szubjektív véleményüket kértük azzal kapcsolatban, hogy elégedettek-e a járványhelyzetben a munkájukkal, milyen mértékben tartják magukat sikeresnek, és mennyire találtak örömet az online tanítás során. Ezeket a véleményeket összevetettük az általuk befektetett munkaórák mennyiségével (2. táblázat).

2. táblázat. A pedagógusok munkamennyisége és szubjektív élményei az online oktatással kapcsolatban (1-nagyon nem, 5 - nagymértékben)

\begin{tabular}{|l|c|c|c|}
\hline & Elemszám & Átlag & Szórás \\
\hline $\begin{array}{l}\text { Elégedettség a járványhelyzet } \\
\text { megoldásával }\end{array}$ & 123 & 4,12 &, 685 \\
\hline $\begin{array}{l}\text { Örömet okoz a tanítás az } \\
\text { online oktatás idején }\end{array}$ & 124 & 3,02 & 1,122 \\
\hline Sikerélményt nyújt a tanítás & 124 & 3,12 & 1,086 \\
\hline $\begin{array}{l}\text { A tanítással kapcsolatos } \\
\text { munkaórák }\end{array}$ & 124 & 4,43 &, 808 \\
\hline
\end{tabular}

Leginkább azzal vannak a pedagógusok megelégedve, ahogy az online oktatási helyzetet megoldották (5-fokú skálán, ahol 1 - egyáltalán nem, 3 - közepes, 5 - teljes mértékben). Az átlagérték 4,12, vagyis ,inkább igen” választ adtak leggyakrabban, elégedettek voltak a helyzet kezelésével a saját részükről. Jelentősen megnőtt a munkaórák száma (ebben a kérdésben a változás mértékét kérdeztük, 3 - nem változott, 5 - sokkal több az online oktatás idején). A szubjektív sikerélmény és a tanítás során átélt öröm érzését közepes szintünek ítélték.

A négy kérdés együttjárását a 3. táblázatban láthatjuk. 
N. Kollár Katalin: Az online oktatás tapasztalatai és gyakorlata a pedagógusok nézőpontjából

3. táblázat. A szubjektív élmények és a befektetett munka közti kapcsolat a járványhelyzetben (korr. szign. $* * 0,01 * 0,05$ )

\begin{tabular}{|c|c|c|c|c|c|}
\hline & & $\begin{array}{l}\text { Elégedettség } \\
\text { a járvány- } \\
\text { helyzet meg- } \\
\text { oldásával }\end{array}$ & $\begin{array}{c}\text { Örömet okoz } \\
\text { a tanítás az } \\
\text { online oktatás } \\
\text { idején }\end{array}$ & $\begin{array}{l}\text { Siker- } \\
\text { élményt } \\
\text { nyújt a } \\
\text { tanítás }\end{array}$ & $\begin{array}{l}\text { A tanítással } \\
\text { kapcsolatos } \\
\text { munkaórák }\end{array}$ \\
\hline \multirow{3}{*}{$\begin{array}{l}\text { Elégedettség } \\
\text { a járvány- } \\
\text { helyzet meg- } \\
\text { oldásával }\end{array}$} & Pearson-korreláció & 1 &, $275^{* *}$ &, $353^{* *}$ & 023 \\
\hline & Sig. (2-oldalú) & & 002 & ,000 & ,803 \\
\hline & elemszám & 123 & 123 & 123 & 123 \\
\hline \multirow{3}{*}{$\begin{array}{l}\text { Örömet okoz } \\
\text { a tanítás az } \\
\text { online okta- } \\
\text { tás idején }\end{array}$} & Pearson-korreláció & $275^{* *}$ & 1 &, $784^{* *}$ &,- 101 \\
\hline & Sig. (2-oldalú) &, 002 & & 000 & ,264 \\
\hline & elemszám & 123 & 124 & 124 & 124 \\
\hline \multirow{3}{*}{$\begin{array}{l}\text { Sikerél- } \\
\text { ményt nyújt } \\
\text { a tanítás }\end{array}$} & Pearson-korreláció &, $353^{* *}$ &, $784^{* *}$ & 1 &,$- 189^{*}$ \\
\hline & Sig. (2-oldalú) &, 000 &, 000 & & ,036 \\
\hline & elemszám & 123 & 124 & 124 & 124 \\
\hline \multirow{3}{*}{$\begin{array}{l}\text { A tanítással } \\
\text { kapcsolatos } \\
\text { munkaórák }\end{array}$} & Pearson-korreláció & 023 &,- 101 &,$- 189^{*}$ & 1 \\
\hline & Sig. (2-oldalú) &, 803 & ,264 &, 036 & \\
\hline & elemszám & 123 & 124 & 124 & 124 \\
\hline
\end{tabular}

Az elégedettség alacsony szinten jár együtt a tanítás során érzett sikerélménnyel és az átélt öröm mértékével. A sikerélmény és az ezzel járó öröm érzése magasan korrelál $(\mathrm{r}=0,767)$, azonban a befektetett munka mennyisége független az átélt örömtöl, ami, mint láttuk, közepes intenzitással jellemezhető élmény ebben az időszakban. Viszont a sikerélmény, ha alacsony szinten is, de fordított összefüggést mutat a befektetett munkával $(\mathrm{r}=-0,187)$, azaz minél több (túl)munkát követel meg ez a helyzet, annál kevésbé érzi magát sikeresnek a pedagógus.

Azt láthatjuk, hogy a pedagógusok érzik, hogy a munka, amit végeztek az online oktatás során, az elvárható szintnek megfelelő (elégedettek a munkával), ugyanakkor ez lényegesen kevesebb örömet és sikerélményt nyújtott számukra.
Az elégedettség alacsony szinten jár együtt a tanítás során érzett sikerélménnyel és az átélt öröm mértékével. A sikerélmény és az ezzel járó öröm érzése magasan korrelál ( $r=0,767)$, azonban a befektetett munka mennyisége független az átélt örömtól, ami, mint láttuk, közepes intenzitással jellemezhetó élmény ebben az idószakban. Viszont a sikerélmény, ha alacsony szinten is, de forditott összefüggést mutat a befektetett munkával ( $r=-0,187)$, azaz minél több (túl)munkát követel meg ez a helyzet, annál kevésbé érzi magát sikeresnek a pedagógus. 


\section{A pedagógusok által alkalmazott módszerek}

A tanításhoz használt módszerek gyakoriságát a 15. ábrán mutatjuk be. Az 5-fokú skálán az 1 - egyáltalán nem, 2 - ritkán, 3 - az órák felében, 4 - gyakran, 5 - szinte mindig gyakoriságnak felel meg.

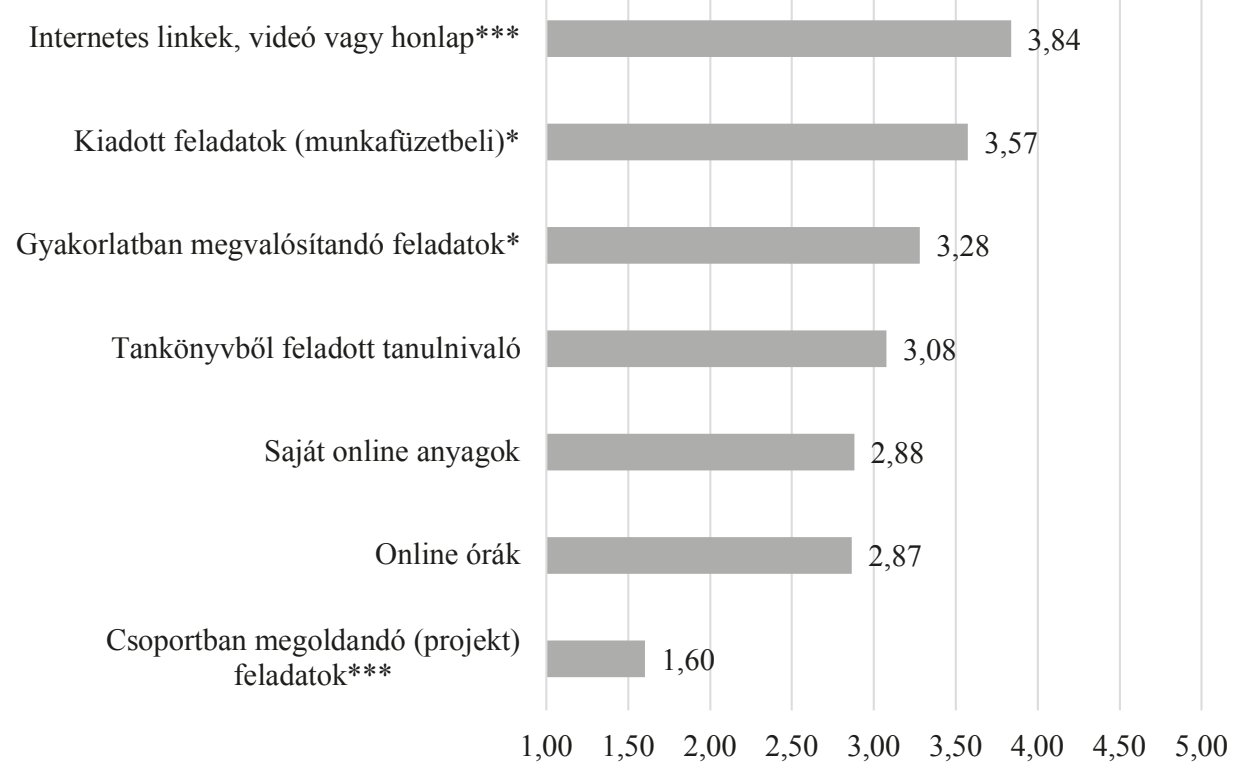

15. ábra. A pedagógus által követett gyakorlat az online oktatás során (1-egyáltalán nem volt, 2 - ritkán, 3 - az órák felében, 4 - gyakran, 5 - szinte mindig)

Az online oktatás során jelentősen mértékű az internetes anyagok, linkek, videók használata, valamint a munkafüzetben vagy feladatgyüjteményből adott feladatok mennyisége. A korábbi gyakorlatot egyik módszer esetén sem kérdeztük. Ez tudatos választás volt részünkről, mert nem azt akartuk mérni, hogy mennyire korszerü vagy változatos a pedagógusok által alkalmazott módszertár általában, hanem hogy milyen képet kapunk a módszerek használatáról ebben az új helyzetben. Az IKT-eszközök használata nem általános a közoktatásban, így az internetes linkek stb. használatának 3,8-es átlagértéke, vagyis a gyakori használata alapján feltételezhetjük, hogy a pedagógusok jelentős mértékben alkalmazkodtak az új helyzethez (15. ábra). A válaszok szórása is jelentős, $\mathrm{s}=1,125$ (lásd 7. táblázat), ami azt jelzi, hogy ebben nagyok az egyéni különbségek.

Hasonló képet láttunk akkor is, amikor a segítségül használt forrásokról kérdeztünk. $\mathrm{Az}$ internetes források jelentős segítséget jelentettek (és ezt látni a diákok válaszaiból is, amelyről egy következő cikkben számolunk be: a diákok is hasznosnak tartották ezeket a forrásokat).

Összehasonlítottuk a különböző szakos tanárok válaszait az internetes anyagok használatában, vagyis a tanító, humán, reál, készségtárgyat oktató és vegyes (tanító, humánreál, illetve ezek készségtárggyal való kombinációja) csoportokat vetettük össze. Nem találtunk különbséget az öt csoport közt (egyszempontos ANOVA n.s.).

Az egyénileg megoldandó, például munkafüzet-feladatok nem csak az online helyzetben gyakoriak, a házi feladatok általában ilyen típusúak. Ebben sem találtunk különbséget 
a szakok szerinti öt csoport közt (egyszempontos ANOVA n.s.). Az egyénileg megoldandó feladatok használata az online oktatás idején is a gyakori megoldások közé tartozik. Korántsem lehetünk azonban nyugodtak a tekintetben, hogy a diákok szempontjából a nagyarányú önálló feladat megfelelő módja-e a hatékony tanulásnak, különösen akkor, ha ezekhez a segítség nyújtása vagy önálló megoldásának ellenőrzése online körülmények közt kevéssé megvalósítható, helyességének ellenőrzése viszont nagymértékben megnöveli a tanári munkamennyiséget.

A gyakorlatban megvalósítandó feladatokat az egész mintát tekintve kevéssel gyakrabban mint az órák felében alkalmazták (4. táblázat).

4. táblázat. A gyakorlatban megoldandó feladatok gyakorisága a pedagógusok szakja szerinti bontásban (érték 1-5, 3 = nem változott)

\begin{tabular}{|l|c|c|c|}
\hline & Elemszám & Átlag & Szórás \\
\hline Teljes minta & 143 & 3,27 & 1,198 \\
\hline Tanító & 28 & 3,21 & 1,197 \\
\hline Humán & 45 & 3,27 & 1,009 \\
\hline Reál & 24 & 2,71 & 1,429 \\
\hline Készségtárgy & 19 & 4,00 & 1,202 \\
\hline Vegyes szakpárt oktató & 27 & 3,30 & 1,068 \\
\hline
\end{tabular}

Ezt az eredményt érdemes a továbbiakban pontosabban megvizsgálni, mert sajnos a megfogalmazás nem zárja ki, hogy a pedagógusok egy része ebbe beleértette a példamegoldást, vagy például alsósok esetén az írás vagy olvasás gyakorlását is. Ez a kérdés azért vetődik fel, mert ez az arány a szokásos iskolai gyakorlathoz képest (N. Kollár és Felvinczi, 2001) meglehetősen magas. Ha itt valóban az otthoni kísérletezés vagy a tanultak tárgyi megvalósítását sikerült mérnünk, akkor azt állapíthatnánk meg, hogy az eddigi módszerekhez képest gyökeres fordulattal találkozunk. A kérdöív egyéb válaszai alapján ezt kevéssé tartjuk valószínünek.

A két kérdés közti összefüggés további vizsgálatával információkhoz juthatunk azzal kapcsolatban, hogy itt valóban manuális tevékenységről van-e szó, vagy az egyéni feladatokra vonatkozó válaszok újbóli megjelenéséről. Egyrészt megnéztük, hogy a készségtárgyak esetén a gyakorlatban megoldandó feladatok gyakoribbak-e, mint más tárgyak esetén, másrészt megvizsgáltuk, hogy mekkora a gyakorlatban megoldandó feladatok korrelációja az egyéni feladatokra vonatkozó kérdéssel.

A tanító, humán és reál szakosok és a készségtárgyak oktatói közt a várt irányban találunk különbséget a gyakorlatban megoldandó feladatok esetén. A tanító, humán és reál szakosok adnak kisebb arányban gyakorlatban megoldandó feladatot, míg a készségtárgyakat tanítók lényegesen több ilyen feladatot adnak (4. táblázat, egymintás ANOVA $\mathrm{F}=3,300, \mathrm{p}<0,05)$.

A módszerek közti korrelációk vizsgálata (5. táblázat) nem támasztja alá azt a feltételezésünket, hogy az egyéni feladatok és a gyakorlatban megoldandók összecsúsztak, a kétféle válasz közt nem találtunk kapcsolatot. Ez azonban nem zárja ki, hogy a feladatmegoldás és az alap-kultúrtechnikák gyakorlása vagy akár a fogalmazás írása szintén a „gyakorlatban megoldandó” kategóriába kerülhetett. 


\begin{tabular}{|c|c|c|c|c|c|}
\hline \multicolumn{6}{|c|}{ 5. táblázat. Az alkalmazott módszerek közti korrelációk $(+p<0,10, * * * p<0,001)$} \\
\hline & & $\begin{array}{l}\text { Online } \\
\text { órák }\end{array}$ & $\begin{array}{l}\text { Kiadott felada- } \\
\text { tok (munka- } \\
\text { füzet stb.) }\end{array}$ & $\begin{array}{c}\text { Tankönyvböl } \\
\text { feladott } \\
\text { tanulnivaló }\end{array}$ & $\begin{array}{c}\text { Gyakorlati } \\
\text { feladat }\end{array}$ \\
\hline \multirow{3}{*}{ Online órák } & Pearson-korreláció & 1 &,$- 155+$ &,- 122 &,- 096 \\
\hline & Sig. (2-oldalú) & & 055 & 133 & ,237 \\
\hline & elemszám & 156 & 153 & 153 & 154 \\
\hline \multirow{3}{*}{$\begin{array}{l}\text { Kiadott } \\
\text { feladatok } \\
\text { (munkafüzet } \\
\text { stb.) }\end{array}$} & Pearson-korreláció &,- 155 & 1 & ,596 &,- 085 \\
\hline & Sig. (2-oldalú) & 055 & & 000 & ,295 \\
\hline & elemszám & 153 & 155 & 153 & 153 \\
\hline \multirow{3}{*}{$\begin{array}{l}\text { Tankönyvből } \\
\text { feladott } \\
\text { tanulnivaló }\end{array}$} & Pearson-korreláció &,- 122 &, $596^{* * *}$ & 1 &,- 005 \\
\hline & Sig. (2-oldalú) & ,133 &, 000 & & ,955 \\
\hline & elemszám & 153 & 153 & 155 & 154 \\
\hline \multirow{3}{*}{$\begin{array}{l}\text { Gyakorlati } \\
\text { feladat }\end{array}$} & Pearson-korreláció &,- 096 &,- 085 &,- 005 & 1 \\
\hline & Sig. (2-oldalú) & 237 & ,295 & ,955 & \\
\hline & elemszám & 154 & 153 & 154 & 157 \\
\hline
\end{tabular}

A tankönyvből feladott tanulnivaló az órák kb. felében jellemző. A szakok összehasonlításában az eltérés szintén a várt irányú. A tanító, humán és reál szakosok oktatói adnak nagyobb arányban ilyen feladatot, míg a készségtárgyakat tanítók lényegesen kevesebbet (egymintás ANOVA $\mathrm{F}=3,383, \mathrm{p}<0,05$ ).

Az online órák a tanórák közel felében valósultak meg (átlag: 2,87). Ez az arány valószínűleg a racionális mérték, a teljes heti óraterhelés online keretek közt nagyon megterhelő lehetne. Itt a kérdés csupán az, hogy ez egyenletesen oszlik-e meg a tantárgyak közt, vagy van-e olyan tárgy, ahol aránytalanul több online óra van, vagy egyáltalán nincs online óra. A szakokat összehasonlítva itt is találunk különbséget. A tanítók és a készségtárgyak oktatói tartanak kevesebb online órát (egymintás ANOVA F $=3,618, p<0,01$ ).

Az online órák mennyisége szempontjából az alsó és felső tagozat közt csak tendenciaszintü a különbség, a felső tagozatban van több online óra (átlag: $2,71, p<0,10$ ). Ugyancsak tendenciaszinten magasabb a felső tagozathoz képest a szakgimnázium online óraszáma (átlag 3,25, p <0,10), egyedül a gimnázium emelkedik ki (itt az átlag 3,79, $\mathrm{p}<0,01$ ) a felső tagozathoz képest (egymintás ANOVA $\mathrm{F}=6,636618, \mathrm{p}<0,001$ ). Az itt kibontakozó trend, hogy az alsó tagozatnak van legkevesebb online órája, ennél több a felső tagozatnak, majd a szakgimnáziumnak, és legtöbb a gimnáziumnak, természetes válasz a diákok életkorából adódó különbségekre. A teljes képhez tartozik, hogy a gimnázium és a szakgimnázium pedagógusainak onlineóra-tartási gyakorlata nem különbözik szignifikánsan. Megnyugtató körülmény, hogy a különbségek alapvetően az életkorral magyarázhatóak. Kérdés azonban, hogy az alsó tagozat kevés online órája (átlag: 2,28, vagyis a többségük ritkán tartott online órát) nem azt jelenti-e, hogy túlzott mértékben a szülökre hárult az alsós tanulók oktatása.

A szakgimnáziumok helyzete további vizsgálatokat igényel, mivel a mintánkban a gimnáziumok esetén túlreprezentáltak a 6 és 8 osztályos, így kisebb korosztályt is oktató pedagógusok.

Viszonylag gyakran, közel az esetek felében a pedagógusok maguk készítette vagy internetről letöltött online anyagokat használtak. Ennek előnye, mint ahogy a diákok és a pedagógusok is visszajelezték, hogy ezek bármikor újra meghallgathatóak. 
Ami viszont szinte teljesen hiányzott, az a diákok együttmüködését igénylő páros és csoportfeladatok. Ennek két következménye van: egyrészt a diákok magányosságát fokozza, hogy a pedagógusok a feladatok egyéni megoldását várják el, másrészt annak az esélye is erősen lecsökken, hogy aki nem érti az anyagot, annak az osztálytárs segítséget nyújthatna (lásd tutorális tanítás).

\section{A diákok tanulásának és értékelésének jellemzői}

A továbbiakban azt kérdeztük a pedagógusoktól, hogy változott-e, és ha igen, milyen irányban és milyen mértékben a teljesítményértékelési gyakorlatuk, a diákok hozzáállása a tanuláshoz és az eredményességük tanulmányi téren. Végezetül a diákokkal való kapcsolatukat és a diákok közérzetének változását ítélték meg. Minden kérdésnél ötfokú Likert-skálát használtunk, ahol a hármas érték a korábbi helyzethez képest a változás hiányát, a három alatti értékek a helyzet romlását és a 4-es és 5-ös érték a javulást jelentette. (Ahol a kérdés fordított volt, ott a grafikon értékeit megfordítottuk.). A változást a grafikonokon *-gal jeleztük (a szokásos szignifikanciaszintekkel $* \mathrm{p}<0,05,{ }^{*} \mathrm{p}<0,01$, *** $\mathrm{p}<0,001)$, a t értékeket a 7. táblázatban közöljük.

A pedagógusok teljesítményértékelési gyakorlatának alakulását, a diákok hozzáállását a tanuláshoz és az eredményességüket tanulmányi téren a 16. ábrán mutatjuk be.

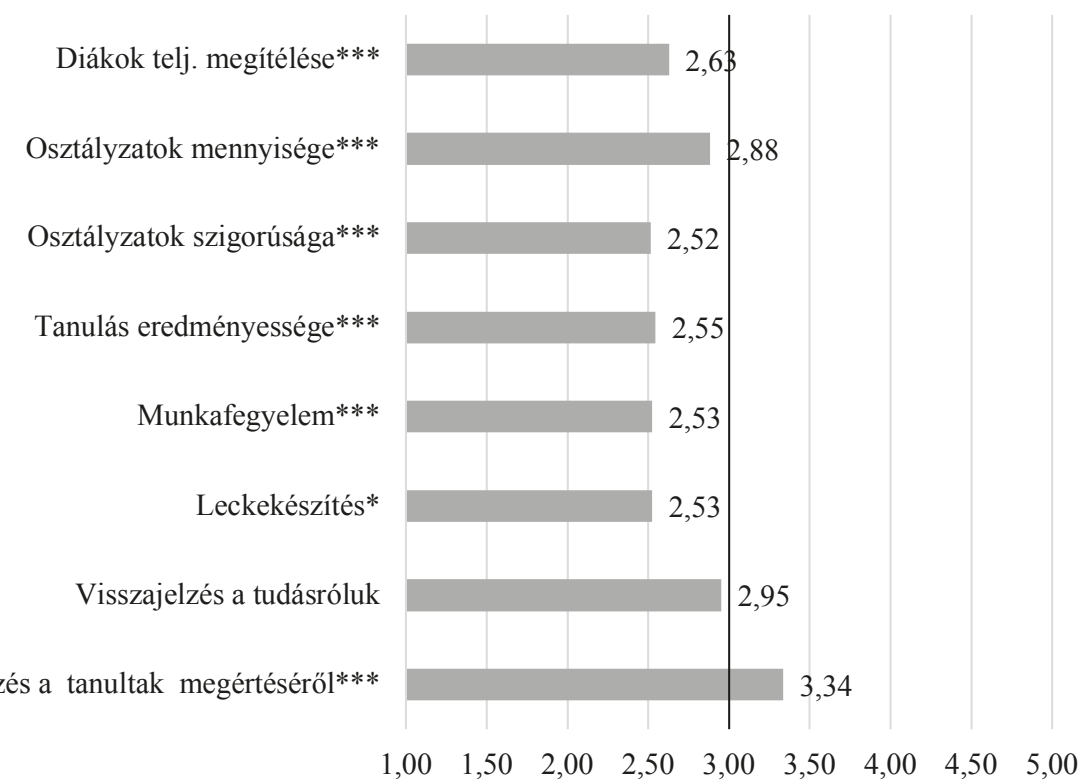

16. ábra. Diákok munkavégzésének jellemzöi és a teljesitmény értékelése a pedagógus részéröl

A pedagógusok teljesítményértékelési gyakorlata szempontjából a diákok tudásáról kapott visszajelzés mennyisége nem változott, ugyanakkor csökkent a jegyek mennyisége, és a tanárok bizonytalanabbak lettek abban, hogy mennyire pontosan tudják megítélni a diákok teljesítményét. Azt észlelik a pedagógusok, hogy a diákok munkafegyelme és tudása romlott, kevésbé készítik el a házi feladatokat, tanuláshoz való viszonyuk rosszabb (lásd 18. ábra), ugyanakkor ők maguk enyhébben osztályozzák a diákokat. 
Egy kérdésben észleltek kifejezett javulást, még ha a változás mértéke nem is nagy (átlag: 3,29): a diákoktól több visszajelzés érkezett a tanultak megértéséröl (vagy meg nem értéséről). Elgondolkodtató, hogy annak ellenére, hogy ez az információ nagyobb mennyiségü, mint korábban, és a tudásról való visszajelzés mértéke sem csökkent, az az érzése a pedagógusoknak, hogy a diákok tudását nem tudják olyan biztonsággal megítélni, mint korábban. Ennek hátterében elképzelhető, hogy a személyes jelenlét hiánya áll. Ha órán felelnének vagy dolgozatot írnának a diákok, akkor a segédeszközök (puska?) használatát a pedagógusok ellenőrizni tudnák. (Erre az egyik pedagógus utalt is a nyílt kérdésre adott válaszában.) Túlmutat a kérdőív által vizsgáltakon, azonban érdemes ehhez kapcsolni azt a PISA vizsgálatokból tudott eredményt, hogy a magyar diákok a tárgyi tudásban teljesítenek jól, de alulmaradnak a tudás alkalmazásában (Csapó, 2015). Ahhoz, hogy ez megváltozzon, a teljesítmény mérésének nem önmagában a tárgyi tudásra, hanem a tudás alkalmazására és a tanultak alapján a problémákon való gondolkodásra lenne célszerü irányulnia. Vagyis a teljesítmény megítélésének bizonytalansága fakadhat abból, hogy a tudás ellenőrzése nagyobb mértékben a lexikális tudásra irányul, és online körülmények közt szinte lehetetlen annak kivédése, hogy a diákok ehhez segédeszközt használjanak. A távolléti oktatás akkor lehet hatékony, ha nem csupán arról szól a változás, hogy most digitális eszközök segítségével valósítjuk meg a tanítást, azonban a módszerek változatlanok, hanem ha paradigmaváltás is történik (Jakab, 2020).

\section{A diákokkal való kapcsolat és a diákok közérzetének változása}

A kényszerü otthonról tanulás megterhelő mind a pedagógusok, mind a diákok számára. Ennek egyik lényeges összetevője a társas kapcsolatok, a személyes találkozás hiánya. Ezért irányultak a további kérdéseink arra, hogy hogyan alakult a kommunikáció és a pedagógus-diák kapcsolat ebben a helyzetben (17. ábra).



17. ábra. Személyes törödés és tanár-diák kommunikáció 
A diákok közérzetéről kapott visszajelzés mértékében nem volt számottevő változás. Ezt az eredményt érdemes a diákok közérzetének alakulásával összevetni (18. ábra). A diákok közérzete határozottan romlott, és ennek orvoslásában a személyes érdeklődés a diákok pszichés állapotáról segítséget jelenthetne. Úgy is fogalmazhatunk, hogy a diákok pszichés állapotának romlása több visszajelzést indokolna.

A másik szempont, ami a diákok számára nyújthat segítséget, az egyénre szabott támogatás. Határozottan javult a helyzet a pedagógusok véleménye alapján a rászoruló tanulóknak nyújtott egyénre szabott segítség terén, ami a többi kérdésben adott válaszok alapján valószínűsíthetően tanulással kapcsolatos segítségnyújtás. A differenciálás a tehetségesekkel kapcsolatban változatlan mértékü. Vajon mindez elegendő-e ahhoz, hogy a diákok megkapják a kellő támogatást? Egyrészt a tanulással és eredményességgel kapcsolatos korábban bemutatott problémákból, másrészt a diákok pszichés állapotának romlásából következően a válaszunk az, hogy sajnos nem. Annak ellenére kevés a diákokkal való személyes törődés, hogy a pedagógusok a korábbinál több időt fordítanak nevelömunkára és egészségfejlesztésre, az életmóddal kapcsolatos támogatásra. Mindezek mellett azt látjuk, hogy a pedagógusok szerint javult a diákokkal való kapcsolatuk, ami a jelen nehéz körülmények közt mindenképp figyelemre méltó pozitív változás.

Végezetül tekintsük át, hogy a pedagógusok tapasztalatai szerint milyen a diákok pszichés állapota. A 18. ábrán nem csak ezt jelenítjük meg, hanem egy pár olyan szempontot is újra idehoztunk a tanulással kapcsolatban, ami potenciálisan befolyásolhatta a diákok közérzetét.
Határozottan javult a helyzet a pedagógusok véleménye alapján a rászoruló tanulóknak nyújtott egyénre szabott segítség terén, ami a többi kérdésben adott válaszok alapján valószinúsithetốen tanulással kapcsolatos segitségnyújtás. A differenciálás a tehetségesekkel kapcsolatban változatlan mértékú. Vajon mindez elegendö-e ahhoz, hogy a diákok megkapják a kelló támogatást? Egyrészt a tanulással és eredményességgel kapcsolatos korábban bemutatott problémákból, másrészt a diákok pszichés állapotának romlásából következóen a válaszunk az, hogy sajnos nem. Annak ellenére kevés a diákokkal való személyes töródés, hogy a pedagógusok a korábbinál több idót forditanak nevelómunkára és egészségfejlesztésre, az életmóddal kapcsolatos támogatásra. Mindezek mellett azt látjuk, hogy a pedagógusok szerint javult a diákokkal való kapcsolatuk, ami a jelen nehéz körülmények közt mindenképp figyelemre méltó pozitív változás. 


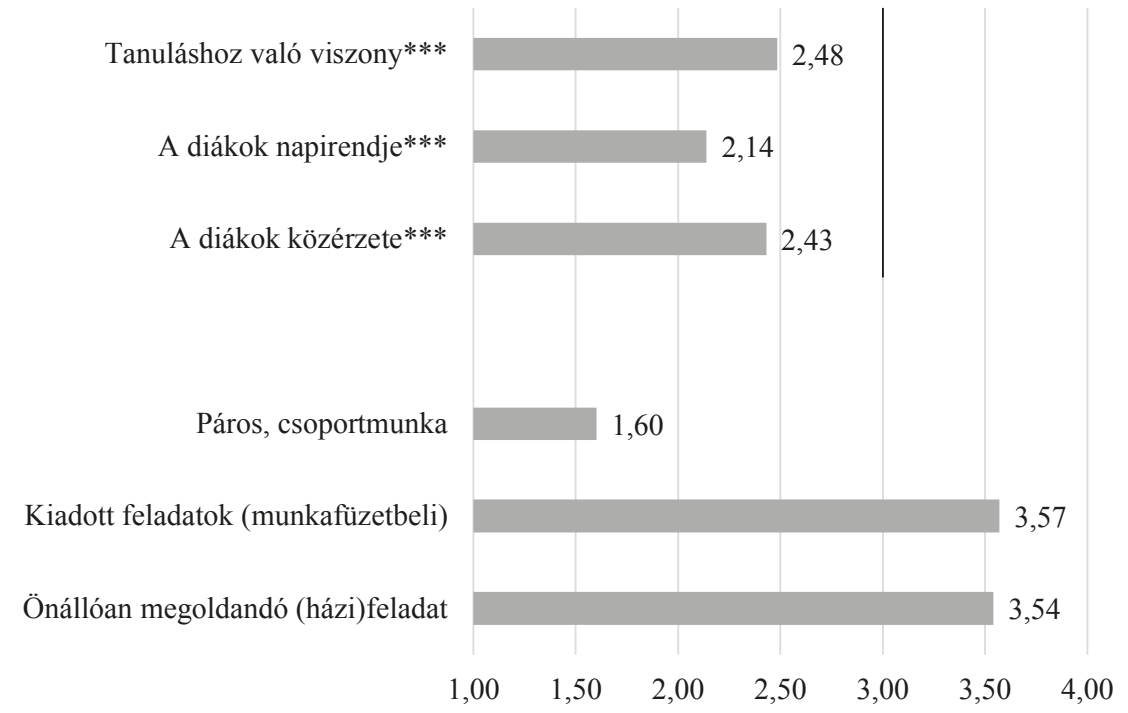

18. ábra. A tanulók feladatai és a közérzetük

A diákok korábban bemutatott tanulmányi teljesítményének romlásán túl a tanuláshoz való viszonyuk, a közérzetük és a napirendjük is lényegesen romlott. Összességében azt mondhatjuk, hogy a távolléti oktatás mind tanulmányi, mind pszichés vonatkozásban fokozta a diákok problémáit. Ez a pedagógusok olvasata, a diákoktól kapott közvetlen eredményeket egy következö tanulmányban mutatjuk be.

6. táblázat. A diákok közérzetének összefüggése más tényezökkel

\begin{tabular}{|c|c|c|c|c|c|}
\hline & & $\begin{array}{c}\text { Diákok } \\
\text { napirendje }\end{array}$ & $\begin{array}{l}\text { A diákok } \\
\text { közérzete }\end{array}$ & $\begin{array}{c}\text { Kapcsolat a } \\
\text { diákokkal }\end{array}$ & $\begin{array}{c}\text { Feladott munka } \\
\text { mennyisége }\end{array}$ \\
\hline \multirow{3}{*}{$\begin{array}{l}\text { Tanulás- } \\
\text { hoz való } \\
\text { viszony }\end{array}$} & Pearson-korreláció & $460^{* *}$ &, $357^{* *}$ &, $220^{* *}$ &,- 013 \\
\hline & Sig. (2-oldalú) & 000 & 000 & ,007 & 892 \\
\hline & elemszám & 140 & 140 & 148 & 116 \\
\hline \multirow{3}{*}{$\begin{array}{l}\text { Diákok } \\
\text { napi- } \\
\text { rendje }\end{array}$} & Pearson-korreláció & 1 &, $345^{* *}$ & ,216* &,- 030 \\
\hline & Sig. (2-oldalú) & & 000 & 010 & ,756 \\
\hline & elemszám & 143 & 137 & 140 & 111 \\
\hline \multirow{3}{*}{$\begin{array}{l}\text { A diákok } \\
\text { közérzete }\end{array}$} & Pearson-korreláció &, $345^{* *}$ & 1 & ,159+ &,- 072 \\
\hline & Sig. (2-oldalú) & ,000 & & 060 & ,459 \\
\hline & elemszám & 137 & 144 & 140 & 109 \\
\hline \multirow{3}{*}{$\begin{array}{l}\text { Kapcsolat } \\
\text { a diákok- } \\
\text { kal }\end{array}$} & Pearson-korreláció &, $216^{*}$ & , 159 & 1 & 133 \\
\hline & Sig. (2-oldalú) & ,010 & 060 & & , 151 \\
\hline & elemszám & 140 & 140 & 155 & 119 \\
\hline \multirow{3}{*}{$\begin{array}{l}\text { Feladott } \\
\text { munka } \\
\text { mennyi- } \\
\text { sége }\end{array}$} & Pearson-korreláció &,- 030 &,- 072 & 133 & 1 \\
\hline & Sig. (2-oldalú) & ,756 & 459 & ,151 & \\
\hline & elemszám & 111 & 109 & 119 & 123 \\
\hline
\end{tabular}


A 6. táblázat korrelációs értékeiből azt láthatjuk, hogy a napirend kiegyensúlyozottságának szerepe jelentős. Minél kiegyensúlyozottabb a diákok napirendje, annál jobb a közérzetük $(r=0,345, p<0,01)$ és annál jobb a tanuláshoz való viszonyuk is $(\mathrm{r}=0,460$, $\mathrm{p}<0,001)$. Nincs adatunk arról, hogy minek köszönhető a kiegyensúlyozott napirend vagy a napi ritmus elvesztése. Az együttjárásokból nem következik, hogy a napirend felbomlása a problémák kiinduló oka, vagy a tanulással kapcsolatos problémák vezetnek a napirend felbomlásához. Joggal feltételezhetjük azonban, hogy azokban a családokban sikerült a napirendet megőrizni, ahol az iskolai tanulás is fontos érték. Ha a kiindulópontot nem is tudjuk azonosítani, azt azonban ezekből az adatokból kijelenthetjük, hogy a napirend megörzése a távolléti oktatás alatt fontos a pszichés egészség szempontjából is. A közérzet és a tanuláshoz való viszony, ha alacsonyabb szinten is, de szintén összefüggést mutat egymással $(\mathrm{r}=0,357, \mathrm{p}<0,001)$.

Elgondolkodtató eredmény, hogy a pedagógussal való kapcsolat, ha alacsony szinten is, a diákok tanuláshoz való hozzáállásával függ össze. Gyenge, de szignifikáns összefüggést kaptunk a tekintetben is, hogy azoknak a diákoknak kiegyensúlyozottabb a napirendje, akikkel a pedagógusok jobb viszonyban vannak $(\mathrm{r}=0,216, \mathrm{p}<0,01)$. Az összefüggések irányára ebből nem tudunk következtetni, azonban mindezek az összefüggések és az együttjárás, amit a diákok közérzete és a pedagógussal való kapcsolatuk közt kaptunk, mind abba az irányba mutatnak, hogy a rendezett napirend, a tanuláshoz való pozitív viszony és a jó tanár-diák kapcsolat hozzájárul a diákok jobb közérzetéhez. A diákok közérzete és a pedagógussal való viszony közt az összefüggést csak tendenciaszinten sikerült kimutatni $(\mathrm{r}=0,159$, $\mathrm{p}<0,10)$, ez azonban akár kitörési pontot is jelenthet azoknak a diákoknak, akiket az online oktatás különösen megterhel akár tanulási vonatkozásban, akár a lelki egészség szempontjából.

A diákok teljesítménye és közérzete független a csoportban kapott feladatok mennyiségének változásától és az egyénileg kapott (munkafüzetbeli) feladatok mennyiségétől, vagyis a diákok gondjainak magyarázatát nem a feladott munka mennyiségében vagy jellegében kell keresni.

A pedagógusok által használt módszerek és a változások számszerü értékeinek további tanulsága az átlagokon túl a szórások alakulása (7. táblázat) is.

\section{Minél kiegyensúlyozottabb a} diákok napirendje, annál jobb a közérzetük ( $r=0,345$, $p<0,01)$ és annál jobb a tanuláshoz való viszonyuk is $(r=0,460, p<0,001)$. Nincs adatunk arról, hogy minek köszönhetó a kiegyensúlyozott napirend vagy a napi ritmus elvesztése. Az együttjárásokból nem következik, hogy a napirend felbomlása a problémák kiinduló oka, vagy a tanulással kapcsolatos problémák vezetnek a napirend felbomlásához. Joggal feltételezhetjük azonban, hogy azokban a családokban sikerült a napirendet megórizni, ahol az iskolai tanulás is fontos érték. Ha a kiindulópontot nem is tudjuk azonosítani, azt azonban ezekból az adatokból kijelenthetjük, hogy a napirend megórzése a távolléti oktatás alatt fontos a pszichés egészség szempontjából is. A közérzet és a tanuláshoz való viszony, ha alacsonyabb szinten is, de szintén összefüggést mutat egymással $(r=0,357$,

$$
p<0,001) \text {. }
$$




\begin{tabular}{|c|c|c|c|c|c|}
\hline \multicolumn{6}{|c|}{$\begin{array}{l}\text { 7. táblázat. A változások és a módszerek a használatának gyakorisága - alapadatok és } \\
\text { az egymintás t-próba (viszonyitási pont 3.0) eredményei }\end{array}$} \\
\hline & Elemszám & $\mathbf{t}$ & Szig. & Átlag & Szórás \\
\hline Tanulóknak önálló feladat & 124 & 6,071 & 000 & 3,54 & ,991 \\
\hline Tanulóknak páros vagy csoportmunka & 123 & $-5,044$ & ,000 & 2,49 & 1,126 \\
\hline Differenciált feladatok a tehetségeseknek & 123 & 1,769 & 079 & 3,16 & 1,019 \\
\hline Segítségnyújtás a tanulóknak & 124 & 6,910 &, 000 & 3,62 & 1,001 \\
\hline $\begin{array}{l}\text { Visszajelzés a tanulóktól a tanultakról } \\
\text { (megértették-e a tanultakat) }\end{array}$ & 122 & 3,740 &, 000 & 3,34 & ,993 \\
\hline $\begin{array}{l}\text { Visszajelzés a tanulóktól, hogy milyen a } \\
\text { tudásuk }\end{array}$ & 124 &,- 611 &, 542 & 2,95 &, 882 \\
\hline Leckekészítés (megfordított tétel) & 124 & 2,332 &, 021 & 2,80 & ,963 \\
\hline Visszajelzés a diákok közérzetéről & 124 & 1,772 & 079 & 3,15 & ,963 \\
\hline Tanítási munkaórák száma & 124 & 19,667 & 000 & 4,43 & ,808 \\
\hline A diákoknak feladott munka mennyisége & 123 & 2,025 &, 045 & 3,16 &, 891 \\
\hline $\begin{array}{l}\text { A tanításon kívüli nevelőmunka (nevelés, } \\
\text { életvezetési tanácsok stb.) }\end{array}$ & 142 & 5,135 &, 000 & 3,51 & 1,147 \\
\hline A diákok teljesítményének megítélése & 140 & $-4,181$ &, 000 & 2,63 & 1,020 \\
\hline Osztályzatok szigorúsága & 130 & $-5,206$ & ,000 & 2,52 & ,739 \\
\hline Osztályzatok mennyisége & 136 & $-4,491$ & 000 & 2,88 &, 853 \\
\hline Online órák & 156 & & & 2,87 & 1,481 \\
\hline Saját online anyagok & 158 & & & 2,88 & 1,438 \\
\hline Internetes linkek, videó vagy honlap & 159 & & & 3,84 & 1,130 \\
\hline Kiadott feladatok (munkafüzetbeli) & 155 & & & 3,57 & 1,206 \\
\hline Tankönyvből feladott tanulnivaló & 155 & & & 3,08 & 1,435 \\
\hline $\begin{array}{l}\text { Egyéni feladatok, amiket a gyakorlatban } \\
\text { kell megvalósítani }\end{array}$ & 157 & & & 3,28 & 1,208 \\
\hline Csoportban megoldandó (projekt) feladatok & 153 & & & 1,60 & 869 \\
\hline $\begin{array}{l}\text { Munkafegyelem, feladatok, leckék } \\
\text { elkészítése }\end{array}$ & 158 & $-6,378$ &, 000 & 2,53 & ,935 \\
\hline A diákok tanulásának eredményessége & 154 & $-6,211$ & 000 & 2,55 & ,908 \\
\hline A diákok napirendje & 143 & $-12,562$ &, 000 & 2,14 & 819 \\
\hline A diákok tanuláshoz való viszonya & 151 & $-7,865$ &, 000 & 2,48 &, 807 \\
\hline A diákok közérzete & 144 & $-7,419$ & ,000 & 2,43 & ,921 \\
\hline A diákok kapcsolata Önnel & 155 & 2,253 & ,026 & 3,12 & 677 \\
\hline
\end{tabular}

A 7. táblázatban tüntettük fel a pedagógusok és diákok mért jellemzőinek a változásait. Az eddigiekhez képest változatlan értékhez (3-as érték) viszonyítottuk a kapott értékeket egymintás t-próbával. Érdemes a 7. táblázatban felfigyelni arra, hogy az 5-fokú skálán mért adataink szórás értékei a 27 kérdésből 15 esetben kifejezetten magasak, ami azt 
mutatja, hogy a tanárok közti különbségek nagyok. Különösen igaz ez a megválasztott módszerek és a tanár-diák kommunikáció tekintetében.

A módszerekkel kapcsolatban számoltunk azzal, hogy ezek alkalmazásának objektív korlátja is lehet, és erre rá is kérdeztünk. Az online órák tartásával kapcsolatban azoknál a pedagógusoknál, akik egyáltalán nem tartottak ilyen órát (a minta 25,2\%-a), az esetek $52 \%$-ában (a minta 13,2\%-a) ennek valóban technikai akadálya is volt. Tekintettel arra, hogy az átállás a távolléti oktatásra egyik napról a másikra történt, ez az arány nem nagy, azonban a vizsgált minta túlnyomórészt fővárosi és részben kisvárosi válaszadókból állt, ezért az általános helyzet ennél rosszabb lehet. Azt mindenesetre jelzi az általunk kapott érték, hogy ezzel a problémával is számolni kell.

\section{Sikerélmények a távolléti tanítás során}

Arra kértük a pedagógusokat, hogy idézzék fel néhány pozitív élményüket az online oktatással kapcsolatban. A válaszokat nyolc nagyobb kategóriába lehetett rendezni.

1. Sikerült megtanítani valamit, ugyanolyan hatékonynak érezték a munkájukat, mint a hagyományos keretek közt (A válaszok jelentős része ezzel a témakörrel volt kapcsolatos):

- „Matematika online órán sikerült megtanítanom az írásbeli osztást, pedig lehetetlennek gondoltam."

- „A tanulók videós beszámolói az egyéni mozgásairól, edzéseiről.”

- „Feltettem egy kérdést és a diákok többsége jelentkezett.”

2. Kiemelkedő teljesítmények:

- „Kaptam néhány igazán remek megoldást.”

- „Nagyszerü project”

- „Amikor egy-egy egy gondolkodós, vélemény-nyilvánítós feladatra őszinte, okos sorokat kapok. $\circlearrowleft ”$

3. A diákok élvezték az általa kínált megoldásokat, pl. online kommunikációt, memoriter kikérdezését:

- „Örültem, amikor örömmel küldtek vissza a feladatokat és ezt kihangsúlyoztak.”

- „A tanulók visszajeleztek, hogy a kiküldött feladat érdekes volt”

- „Flow élmények”

4. A tanár-diák interakció sikeressége vagy örömteli volta:

- „Nagy öröm volt számomra, hogy reggel nyolc óra elött már hallottam a jelentéseket a gyerekektől. Várták, hogy kezdjük az órát.”

- „Küldd el ímélben, hogy érzed magad! - feladatnál, sok tanítványom írta, hogy szívesebben járna iskolába."

- „Sokkal többet kommunikálok a diákokkal.”

- „Igényelték az online beszélgetéseket.”

5. A gyerek jobb teljesítménye, új oldalról való megismerése az online oktatás idején:

- „Van olyan gyerek, aki sokkal jobb teljesítményt nyújt a szülö jelenlétében. Nagyszerü látni, hogy családi körben kibontakozik, megnyilvánul és többre képes a szégyenlös gyerek."

- „Volt egy tanítványom, aki nagyon visszahúzódó, keveset kommunikál. Az online oktatás során messengeren keresztül bátrabb lett, többet beszélgettünk." 
6. Differenciált bánásmód a nehézségekkel küzdőknek:

- „Diák visszajelzett privátban, hogy kétségbeejtőn nem megy a házi. Felhívtam messengeren és segítettem neki. 3 perc volt kb. de neki számított..."

- „Elöfordult, hogy gyermekek többszöri írásbeli magyarázatom után megértették és helyesen megoldották a feladatot."

7. Diákok motiváltan álltak a tanuláshoz:

- „A diákok otthon végzett, motiváltabb, szabadabb feladatmegoldásai."

- „Mindenki megcsinálta a feladatot időre!”

8. A szülőkkel való kapcsolat:

- „A család bevonása az általam kiadott gyakorlatok elvégzésébe. (testnevelés)”

- „Igazán örültem, mikor bekapcsolódott egy-egy szülő is, és később jelezte, hogy így már ő is érti ezt a tananyagot. ( $(\bullet)$ "

- „A szülők és bátrabbak lettek, kérdeztek és érdeklődtek a gyermekük eredményei után."

A kérdés a sikerélményekre vonatkozott, így természetes, hogy hívta azokat a válaszokat, amikben a pedagógusok a tanulással kapcsolatos eredményekröl számoltak be. Ugyanakkor sikerként jelent meg a diákokkal való kapcsolat személyesebbé válása, a törődés a diákokkal és a közvetlenebb kommunikáció is.

\section{Tanulságok és következtetések a pedagógusok válaszai alapján}

A pedagógusok mind iskolán belül, mind iskolán kívül, informális kapcsolatok révén is kaptak segítséget az online oktatáshoz. Bár ez a segítség jelentős mértékü volt, a kapott támogatás összességében alatta maradt a kívánatos mértéknek. Különösen az egyes kollégák, az iskola vezetője és a munkaközösség által nyújtott segítség volt számottevő, valamint nagymértékben támaszkodtak a pedagógusok internetes forrásokra is. Az informatikában jártas szakemberektől ehhez képest kevesebb támogatást kaptak. Mind a kollégákkal, mind az intézmény vezetőjével kapcsolatban néhányan megfogalmazták, hogy soknak találják a tölük kapott (vagy kért?) segítséget. Egyértelmüen az informatikában jártas kollégák segítségét igényelték volna nagyobb mértékben. Ezért javasolható az intézményvezetőknek, hogy az informatikában jártas kollégák tudását érdemes lenne minél szélesebb körben hasznosítani. Van igény az iskolapszichológus és egyéb szakemberek segítségére is, a ténylegesen nyújtott segítség szintje tőlük még alacsony. Velük kapcsolatban érdemes tudatosítani a pedagógusokban, hogy konkrétan milyen területeken lehetne a velük való együttmüködést használni.

Az iskolán kívüli, baráti és családi segítséggel kapcsolatban felmerült, hogy jó lenne, ha nem kellene rájuk ilyen mértékben támaszkodni. A saját tanítványoktól kapott segítségre a pedagógusok alapvetően nyitottak lennének. Úgy véljük, ezt érdemes lenne kihasználni, nyíltan kommunikálni ezt az igényt a diákok felé, mert ez hozzájárulhatna a tanár-diák kapcsolat javulásához.

A pedagógusok közérzete szempontjából az oktatási feladatok megoldását eredményesnek találták, ugyanakkor nagy munkaterhelés-növekedésről számoltak be. A pedagógusok sikerélménye kisebb, ha a feladatokat nagy munkabefektetés árán sikerül elérni. A pedagógusok kiégés-veszélyeztetettségét a tanítás örömforrásként való észlelésének alacsonyabb szintje jelezheti.

A pedagógiai eszközök és módszerek közül a leggyakrabban az internetes honlapokat, videókat használták, valamint a munkafüzetből vagy más forrás alapján feladott 
feladatokat és a gyakorlatban megvalósítható feladatokat. Ez utóbbinak a használata nagyon kedvező, ugyanakkor további vizsgálatokat tartunk szükségesnek annak vizsgálatára, hogy ezek valóban a tanultak alkalmazását jelentették-e. Az alkalmazott módszerek közt egyáltalán nem, vagy ritkán szerepeltek a diákok együttmüködését igénylő páros vagy csoportfeladatok.

A diákok teljesítménye szempontjából kedvező, hogy a hagyományos oktatáshoz képest nőtt a visszajelzés mennyisége arról, hogy a diákok megértették-e a tanultakat, ugyanakkor lényegesen csökkent a tanulás eredményessége, a leckekészítés és általában a diákok munkafegyelme. Bizonytalanabbá váltak a tanárok a diákok teljesítményének megítélésében, kevesebb és enyhébb osztályzatokat adtak. Vagyis összességében romlott a tanulás hatékonysága és az ezzel kapcsolatos visszajelzés is a tanárok részéröl.

A diákok pszichés állapotában is romlást észleltek a pedagógusok, romlott a tanuláshoz való hozzáállás, a diákok közérzete és a napirendjük is. Mindez összefüggésbe hozható a tanár-diák viszony alakulásával: a pozitívabb tanár-diák viszony a diákok jobb pszichés állapotával járt együtt.

A nevelömunka és a tanár-diák kommunikáció szempontjából az eddigiekhez képest pozitívabb a kapott kép. Nőtt a diákok személyes segítése és a neveléssel és életvezetéssel kapcsolatos beszélgetések mennyisége.

\section{A vizsgálathoz használt kérdőív felhasználási lehetőségei}

Az általunk bemutatott eredmények csak korlátozott mértékben általánosíthatóak. Ahhoz, hogy mérleget lehessen húzni a kényszerü távolléti oktatással kapcsolatban, országos reprezentatív felmérésre lenne szükség. A jelenleg rendelkezésünkre álló minta egyrészt kis elemszámú, másrészt csak bizonyos szeletét fedi le a közoktatásnak; megkockáztatjuk, hogy a jobb helyzetben levő iskolák irányában torzít, mivel túlreprezentáltak benne a fővárosi és városi iskolák és a középiskolák közül a 6 és 8 osztályos gimnáziumok tanárai.

Nem is a közoktatással kapcsolatos általános tanulságok megfogalmazása volt az elsődleges célunk, sokkal inkább a lehetséges problémák gyüjtésére törekedtünk. Másrészről egy olyan kérdöívet állítottunk össze, aminek segítségével az iskolapszichológusok, vagy ezek hiányában maguk a pedagógusok is feltérképezhetik a saját intézményük jellemző problémáit. Ezek az adatok reményeink szerint segítséget nyújthatnak ahhoz, hogy a tantestület közösen kidolgozhassa a saját stratégiáját, ha és amikor újra online oktatásra kerül sor, mint ahogy ez be is következett elöbb a középiskolák körében, majd 2021 tavaszán újra a teljes közoktatásban. A kép megrajzolásához a diákok nézőpontja is szükséges, ezzel kapcsolatban egy következő tanulmányt tervezünk. Sőt az alsó tagozat esetén különös jelentősége lehet a szülők átélt tapasztalatainak is, ezért kidolgoztunk egy szülöi változatot is (az összes kérdöív online változata a http://iskolapszichologiai-modszertani-bazis.elte.hu honlapon érhetö el).

Úgy gondoljuk, hogy a jelen vizsgálat egyik fó tanulsága az, hogy a pedagógusok és diákok közérzetének javítására és a tanulás hatékonyságának növelésére első lépésben a tanár-diák kommunikációt érdemes fokozni. így juthatunk el a jelenleginél egyénre szabottabb, a diákok sajátosságait, tempóját és társas igényét is figyelembe vevő gyakorlatig. Az utolsó, nyitott kérdésre adott válaszok alapján a közvetlenebb kommunikáció a pedagógusok számára is örömforrást jelenthet. 


\section{Köszönetnyilvánítás}

Köszönetet mondunk az adatgyüjtésért Aszódi Angyal Andrea, Fábián Natália, Lukács Csaba, Molnár Richárd, Péterfi Eszter, Varga Kata és Vaspál Erika iskolapszichológusoknak és hallgatóknak.

\section{Irodalom}

Aronson, E. (2008). A társas lény. Akadémiai Kiadó

Barth, A. (1992). Burnout bei Lehrern: Theoretische Aspekte und Ergebnisse einer Untersuchung. Hogrefe.

Bashian, A. (1989). Expanding the role of the school psychologist through peer tutoring programs. Kézirat.

Benkovics-Parádi Krisztina (2017). A kiégés jelensége a pedagóguspályán. In N. Kollár Katalin \& Szabó Éva (szerk.), Pedagógusok pszichológiai kézikönyve. III. kötet. Osiris. 112-134.

Csapó Benő (2015). A magyar közoktatás problémái az adatok tükrében. Iskolakultúra, 25(7-8), 4-17. DOI: 10.17543/iskkult.2015.7-8.4

Falus Iván (2007, szerk.). Didaktika. Nemzeti Tankönyvkiadó.

Forrás-Biró Aletta (2019). Tanulásmódszertan és tanulástámogatás a közoktatásban. PhD. disszertáció, ELTE.

Hamre, B. K. \& Pianta, R. C. (2006). Student-Teacher Relationships. In Bear, G. G. \& Minke, K. M. (szerk.), Children's needs III: Development, prevention, and intervention. National Association of School Psychologists. 59-71.

Holecz Anita (2006). Pedagógusjelöltek és pedagógusok személyiség- és megküzdési jellemzői. Alkalmazott Pszichológia, 8(4), 22-40.

Jakab György (2020). ISKOLA - járvány idején (1. rész). Iskolakultúra, 30(9), 64-76. DOI: 10.14232/ iskkult.2020.9.64

Imre Anna (1999). Cigány tanulók a szakmunkásképzö iskolában. Educatio, 8(2), 286-296.

Kagan, S. (2001). Kooperatív tanulás. Önkonet.

Loke, A. J. T. Y. \& Chow, F. L. W. (2007). Learning partnership - the experience of peer tutoring among nursing students: a qualitative study. International
Journal of Nursing Studies, 44(2), 237-244. DOI: 10.1016/j.ijnurstu.2005.11.028

McKinsey \& Company (2007). Mi áll a világ legsikeresebb iskolai rendszerei teljesitményének hátterében? https://mek.oszk.hu/09500/09575/09575.pdf Utolsó letöltés: 2021. 02. 11.

N. Kollár Katalin (2017). Feladatvégzés csoportban, versengés és együttmüködés. In N. Kollár Katalin \& Szabó Éva (szerk.), Pedagógusok pszichológiai kézikönyve. III. kötet. Osiris. 213-263.

N. Kollár Katalin, Martonné Tamás Márta, Porkolábné Balogh Katalin \& Gyenei Melinda (1999). Iskolás gyerekek terhelési szintje, pszichoszomatikus egészségi állapota és társas kapcsolatai. Magyar Pszichológiai Szemle, 54(3), 405-428.

N. Kollár Katalin \& Felvinczi Katalin (2001). Az „egészséges élet” kísérleti tantárgy vizsgálata óramegfigyelésekkel. Alkalmazott Pszichológia, 3(4), 73-88.

Paksi Borbála \& Schmidt Andrea (2006). Pedagógusok mentálhigiénés állapota. Új Pedagógiai Szemle, 56(6), 48-64.

Slavin R. E. (1986). Cooperative learning: engineering social psychology in the classroom. In Feldman, R. S. (szerk.), The Social Psychology of Education: Current Research and Theory. Cambridge University Press. 153-169.

Slavin, R. E. (2014). Educational Psychology. Theory and Practice. Pearson.

Szabó Lilla, Rausch Attila \& Zsolnai Anikó (2019). A pedagógus-diák közötti kötődés jellemzése egy hazai vizsgálat tükrében. Iskolakultúra, 29(2-3), 22-38. DOI: 10.14232/iskkult.2019.2-3.22

Van der Doef, M. \& Maes, S. (1999). The Job Demand-Control (-Support) model and psychological well-being: A review of 20 years of empirical research. Work \& Stress, 13(2), 87-114. DOI: $10.1080 / 026783799296084$ 


\begin{abstract}
Absztrakt
A koronavírus-járvány miatt 2020 tavaszán bevezetett kényszerü távolléti oktatással kapcsolatban kérdőíves felmérést végeztünk pedagógusok körében. A vizsgálat célja alapvetően a kialakult helyzet felmérése volt. A kérdőívben egyrészt azt vizsgáltuk, hogy a pedagógusok milyen segítséget kaptak és igényeltek volna, másrészt a közérzetüket és az oktatás változásait vizsgáltuk, mind az alkalmazott módszerek, mind az általuk megítélt eredményesség tekintetében. Végül kérdeztük őket a diákokkal való kapcsolatukról és a diákok közérzetéről is. Eredményeink szerint a pedagógusok, bár jelentős segítséget kaptak, de sokszor nem azoktól, akiktől szerettek volna. Alapvetően informatikában jártas kollégák segítségét hiányolták, míg néhány esetben sokallották az intézmény vezetőjétől, a munkaközösségtől, a barátoktól és egyes kollégáktól kapott segítséget. Az általuk befektetett munka jelentősen nőtt az online oktatás idején, kevésbé tudták megítélni a diákok tudását és kevésbé szigorúan osztályoztak. Annak ellenére, hogy a diákokkal való személyes törődés nőtt, a diákok közérzetének, tanuláshoz való viszonyának és napirendjének romlásáról számoltak be, miközben jelentősen nőtt az önállóan megoldandó feladataik száma és csökkent a diákok együttmüködését igénylő páros és csoportfeladatok aránya. Tetten érhető, hogy a különböző helyzetben levő pedagógusok közt mind módszerválasztásban, mind eredményességben jelentős különbségek vannak. A nehézségek okait összefüggésbe hoztuk az alkalmazott módszerekkel, és javaslatokat fogalmaztunk meg az adatok tükrében a lehetséges változtatások irányára.
\end{abstract}

